NBER WORKING PAPER SERIES

\title{
ACQUIRING CONTROL IN EMERGING MARKETS: EVIDENCE FROM THE STOCK MARKET
}

\author{
Anusha Chari \\ Paige P. Ouimet \\ Linda L. Tesar \\ Working Paper 10872 \\ http://www.nber.org/papers/w10872
NATIONAL BUREAU OF ECONOMIC RESEARCH
1050 Massachusetts Avenue
Cambridge, MA 02138
October 2004

The authors thank Andrew Bernard, Michael Dooley, Atif Mian, Arturo Bris, Peter Henry, Luigi Zingales and seminar participants at Berkeley, Dartmouth, Princeton, IFM-NBER Summer Institute, EFA MeetingMaastricht, the 9th Mitsui Life Emerging Markets Symposium, and the Department of Economics and the Finance Group at the University of Michigan for helpful comments and suggestions. Chari thanks the Mitsui Life Financial Research Center for financial support. Chari and Tesar acknowledge a grant from the Center for International Business Education at the University of Michigan. The views expressed herein are those of the author(s) and not necessarily those of the National Bureau of Economic Research.

(C) 2004 by Anusha Chari, Paige P. Ouimet, and Linda L. Tesar. All rights reserved. Short sections of text, not to exceed two paragraphs, may be quoted without explicit permission provided that full credit, including (c) notice, is given to the source. 
Acquiring Control in Emerging Markets: Evidence from the Stock Market Anusha Chari, Paige P. Ouimet, and Linda L. Tesar

NBER Working Paper No. 10872

October 2004

JEL No. F3, G3

\title{
ABSTRACT
}

When firms from developed markets acquire firms in emerging markets, market-capitalizationweighted monthly joint returns show a statistically significant increase of $1.8 \%$. Panel data estimations suggest that the value gains from cross-border M\&A transactions stem from the transfer of majority control from emerging-market targets to developed market acquirers - joint returns range from $5.8 \%$ to $7.8 \%$ when majority control is acquired. Announcement returns for acquirer and target firms estimate the distribution of gains and show a statistically significant increase of $2.4 \%$ and $6.9 \%$, respectively. The evidence suggests that the stock market anticipates significant value creation from cross-border transactions that involve emerging-market targets leading to substantial gains for shareholders of both acquirer and target firms.

\author{
Anusha Chari \\ Department of Economics \\ University of Michigan \\ 701 Tappan Street \\ Ann Arbor, MI 48109 \\ achari@umich.edu \\ Paige P. Ouimet \\ Department of Economics \\ University of Michigan \\ 701 Tappan Street \\ Ann Arbor, MI 48109 \\ pshelby@umich.edu \\ Linda L. Tesar \\ Department of Economics \\ University of Michigan \\ 701 Tappan Street \\ Ann Arbor, MI 48109 \\ and NBER \\ ltesar@umich.edu
}




\section{Introduction}

Cross-border mergers and acquisitions (M\&A) in emerging markets surged during the 1990s. From 1991 through 2000 cross-border M\&As accounted for $61 \%$ of foreign direct investment (FDI) in Latin America and 48\% in East Asia, up from 10\% and 4\% in the 1980s (Figure 1).

Before the surge in cross-border M\&A, FDI in emerging markets consisted primarily of green-field investments. Cross-border M\&A and green-field investments are conceptually quite different. By definition, green-field investments create value by bringing new investment in physical assets to the recipient country. In contrast, crossborder M\&As involve the foreign purchase of existing assets, which may not necessarily increase productive capacity (Froot, 1991).

Alternatively, cross-border M\&A transactions may create value by allowing firms to vertically integrate lines of production across borders and through positive externalities such as transfers of technology and skills between firms (Andrade, Mitchell, and Stafford, 2001). M\&A transactions will also create value if they provide acquirers with access to target markets or lower the cost of capital for target firms (Caves 1996).

Do cross-border mergers and acquisitions create surplus value in emerging markets? This paper uses the stock market to provide an answer. When a cross-border M\&A transaction takes place, there are two parties to consider - a developed-market acquirer and an emerging-market target. On the date that a cross-border M\&A transaction is announced, changes in acquirer- and target-firm stock prices reveal information about (i) the potential wealth creation from the transaction, and (ii) the distribution of the gains and losses from the transaction to the acquirer and target firms. 
We use the Securities Data Corporation (SDC) Thompson's International Mergers and Acquisitions database to identify merger and acquisition events in emerging markets over the period 1988-2003. Stock price information is taken from Datastream and Bloomberg. Changes in market-weighted joint returns for acquirers and targets serve as a summary statistic for value creation through cross-border M\&A activity. Changes in acquirer- and target-firm stock prices provide an estimate of the value gains or losses to their respective shareholders.

At first blush, our results suggest that cross-border M\&A transactions lead to a creation of surplus value. Panel data estimations suggest that market-capitalizationweighted joint returns for targets and acquirers show a statistically significant increase of $1.8 \%$ when a cross-border M\&A transaction is announced. Joint-return increases are robust to the inclusion of controls for country, time, industrial diversification, method of payment effects, as well as acquirer- and target-firm characteristics such as size and liquidity.

Moving beyond the basic issue of measuring the creation of surplus value, lies the more fundamental question of why firms would be worth more under foreign rather than domestic control (Kindleberger, 1969). A key feature of the cross-border M\&A transactions in our data is the acquisition of majority control by developed market acquirers. For instance, 628 out 842 acquirers in the sample did not own any shares in the target before the cross-border M\&A announcement, but moved to majority or full ownership following the announcement. For 153 transactions where the acquirer had a minority interest in the target, 31 resulted in a transfer of majority control or full ownership following the transaction. The pattern of shifting majority control is consistent with the evidence that when foreign ownership restrictions are removed in an 
emerging market like Mexico, affiliates of US multinationals move to majority or full foreign ownership (Perez-Gonzalez, 2004).

Acquiring majority control can be important particularly in situations where it is difficult to write or enforce complete contracts (Coase, 1937; Alchian, Crawford, and Klein, 1978; Grossman and Hart, 1986; Williamson, 1979). Problems of ineffective monitoring and incomplete contracting are especially important in emerging markets (Antras, 2003; Dyck and Zingales, 2004; La Porta, Lopez de Silanes, Shleifer, and, Vishny 1998). By acquiring majority control, developed-market acquirers in effect extend the boundaries of the firm across borders to include the emerging-market targets. In a setting with weak property rights, acquiring majority control may create the necessary incentives to transfer technology and capital to the target firms.

Panel data estimations in this paper verify that the stock market anticipates significant gains when the acquirer gains majority control of the target. Joint returns in the announcement window are significantly higher when a developed market acquirer gains majority control of an emerging market target ranging from $5.8 \%-7.8 \%$ in alternative specifications. The result is consistent with studies that examine the effects of FDI and conclude that FDI results in improvements in productivity (Aitkin and Harrison, 1999) and that the productivity gains resulting from FDI are concentrated in plants where multinational firms acquire majority or full ownership (Perez-Gonzalez, 2004).

Next, we turn to the distribution of gains. Following the Williams Act (1968), studies based on US data suggest that a lion's share of the combined gains from domestic M\&A transactions accrue to target-firm shareholders leaving little or no gains for the shareholders of the acquiring firms (Jensen and Ruback, 1983; Brickley, Jarrell, and Netter, 1988; Andrade, Mitchell, and Stafford, 2001). The estimations in this paper show 
that developed-market acquirers experience a statistically significant gain of $2.4 \%$ when they announce M\&A transactions in emerging markets. On average, monthly returns for target firms are also positive when a cross-border M\&A transaction is announced-and equal $6.8 \%$ on a market-adjusted basis. Put another way, the announcement returns translate to a median market capitalization gain of $\$ 117$ million and $\$ 3.12$ million for the shareholders of acquirer and target firms, respectively. Distinct from domestic transactions, the distribution of gains appears to shift in favor of developed-market acquirers in emerging-market transactions.

Would the acquirers in our sample gain from the acquisition of control in M\&A transactions regardless of the geographic location of the target? Or, are the gains particular to the emerging-market context? To test whether majority control matters outright or only in situations where institutions are poor, the announcement returns for developed-market acquirers are compared between developed- and emerging-market M\&A transactions. The estimates suggest that when an acquisition of a target located in the developed markets in our sample, such as, Canada, Europe, Japan, Hong Kong, Singapore, and the United States is announced, acquiring majority control does not lead to an increase in acquirer returns. In contrast, when majority control of an emergingmarket target is announced, acquirer returns show a statistically significant increase of $5.8 \%$ to $12.9 \%$ in alternative specifications. Moreover, the effect of acquiring control appears more important in R\&D-intensive industries where the transfer of proprietary assets is an issue. The transfer of majority control may create value by providing a mechanism through which acquirers are able to lend developed-market institutions to emerging-market targets (Acemoglu and Johnson, 2003; Bris and Cabolis, 2004). 
It is important to caution that the value gains estimated in this paper pertain to specific acquirer-target pairs that engage in cross-border M\&A transactions. As a result, the evidence does not speak to the issue of the welfare implications of cross-border mergers and acquisitions from a general equilibrium perspective. In particular, the results do not provide evidence on the impact of a cross-border M\&A transaction on the other firms in an emerging-market target's industry. The estimates of wealth creation from cross-border M\&A activity cannot, therefore, be generalized to the rest of the emergingmarket economy.

The focus of this paper is on the stock price reaction, an inherently ex-ante measure, to news of an acquisition as a summary statistic to capture the gains and losses from an acquisition. It does not consider whether the synergies from the acquisition as measured by announcement returns are in fact realized. Indeed, the empirical analysis does not look at the ex-post performance of the combined firm. A drawback of ex-post performance measures is that these measures tend to be fraught with endogeneity problems and are sensitive to the choice of different sample periods as well as the benchmark that is used to measure risk (Barber, Lyon, and Tsai, 1999).

In light of these issues, this paper turns to changes in stock prices to derive forward-looking estimates of changes in discounted expected future cash flows when a cross-border acquisition is announced. Illusory or not, the stock market's reaction tells us what the market thinks (Lang and Stulz, 1994). Whether the stock market's reaction is rational or not is a separate question. 


\section{The Data}

The empirical analysis is based on data from SDC Thompson's International Mergers and Acquisitions database. The data include all public and private M\&A transactions involving at least 5\% ownership of the target company. SDC collates information from over 200 English and foreign language news sources, SEC filings and the filings from its international counterparts, trade publications, newswire reports, and proprietary surveys of investment banks, law firms, and other advisory firms.

The sample of emerging market targets covers nine Latin American and East Asian countries over the period 1988-2002. The nine target countries are Argentina, Brazil, Chile, Indonesia, Malaysia, Mexico, Philippines, South Korea, and Thailand. Subsidiary firms of multinational companies domiciled in a developed market are not used in the estimations, because while they are identified as publicly traded firms in the SDC database, they are not necessarily listed on the stock exchanges in the target nations.

For each transaction, the SDC database provides information about the date on which the transaction was announced and the date on which the transaction became effective. The database also provides some characteristics of the target and acquiring firms such as name, nation, industry sector, and primary SIC classification. Many of the transactions contain transaction-specific information such as the percent of shares acquired, the percent of shares owned before and after the transaction is completed, and the percent of shares sought by the acquiring firm. ${ }^{2}$ The paper supplements this data with

\footnotetext{
${ }^{2}$ SDC also provides some information about the nature of the transaction. Cross-border mergers and acquisitions are transacted through a variety of means, from privately negotiated sales to open market tender offers. In the emerging market sample, a significant number of acquisitions are transacted through a third party. In these cases, the target share price is unaffected by possible bidding pressure, and instead, any change in price will reflect the markets view of the value of the new owner relative to the previous owner. However, even with developed-market targets, this bidding pressure infrequently contributes to target price changes as the majority of transactions in the sample are completed without the acquirer directly tapping into the open market.
} 
stock price information from Datastream, Bloomberg and the ISI Emerging Markets Database for the target and acquirer firms. The announcement dates and firm names were cross-checked using Factiva to confirm the identity of the firms as well as doublecheck the announcement dates provided by SDC. Buy and hold returns are constructed using weekly data on stock prices. All returns are denominated in the local currency and the US dollar. For target firms, return data is dropped from sample if during the event window the target security did not change price for more than two consecutive weeks.

The data description covers 1629 M\&A transactions by publicly traded developed market acquirers that involve a publicly traded emerging-market target. Of these transactions, stock price data was available for 379 emerging market firms. The sample of emerging-market targets is supplemented with an additional 1150 observations of developed market acquisitions by the acquirer firms in the sample. These observations cover M\&A transactions that result in a change in majority control in the target firm as well as acquisitions of minority shares - a distinction that is explored in detail in later sections.

\subsection{Cross-Border Mergers and Acquisitions in Emerging Markets}

Table 1 provides a breakdown of M\&A transactions in emerging markets over time by region of target, by target sector, and by country or region of acquirer. The first panel shows the number of M\&A transactions of targets in Asia and Latin America. The number of M\&A transactions increased in both regions over time, with a particularly large increase in the 1998-2002 period (Figure 1). Throughout the sample period the number of cross-border M\&A transactions in Latin America exceeds the number of M\&A transactions in Asia (Table 1). When decomposed by sector, it appears that most 
target firms are either in the finance, insurance, and real estate (FIRE), manufacturing, or utilities sectors. The M\&A transactions appear evenly split between "tradables" and "nontradables" sectors. The bottom panel of the table shows the decomposition by the acquirer's country of origin. US firms acquire roughly $40-50 \%$ of the emerging-market targets while European firms acquire 20-30\%. ${ }^{3}$ Firms in Singapore and Hong Kong made a large number of M\&A transactions in emerging Asia during 1998-2002.

The difference in the timing of M\&A activity in the two regions is largely due to differences in the regulations governing foreign participation in domestic capital markets. Both regions undertook capital market liberalizations in the middle to late 1980s and early 1990s. However, the degree of openness varied across countries. Latin America began its process of capital market liberalization in the early 1990s and actively sought foreign investment in its newly privatized industries. The market for corporate control in Asia was more restricted as evidenced by the low volume of mergers and acquisition activity prior to the Asian Crisis in 1997.

In many countries in East Asia, foreign investors were explicitly prohibited from gaining a controlling share in local firms. For example, in 1996 the ceiling on the amount of stock foreigners could acquire in all Korean companies without the approval of the board of directors was only $18 \%$. Another feature of the market for corporate control in Korea was that cross-holdings across business groups (Chaebols) were substantial. At the same time, the voting rights of institutional and minority shareholders were limited. As a result, the founder family could effectively control a business group with a relatively small direct ownership stake in the group.

\footnotetext{
${ }^{3}$ This pattern differs across regions. US and Spanish acquirers account for a larger share of targets in Latin America, Japan, Hong Kong, and Singapore account for a larger share in Asia.
} 
This situation changed dramatically as a consequence of the financial crises that swept through the region during 1997. The IMF bail-out packages to Thailand, Korea, and Indonesia imposed additional conditions such as restructuring domestic capital markets to allow foreign competition in the market for corporate control. The policy recommendations had a dramatic effect on M\&A activity in the region. Figures 2a and $2 \mathrm{~b}$ show the volume of cross-border M\&A in Thailand and Korea, highlighting the relevant changes in policy. The Thai agreement largely affected the foreign ownership of real estate and financial companies. The regulations changed in the second half of 1997, and cross-border mergers and acquisitions peaked shortly thereafter. Similarly, in Korea, regulations allowing foreigners to obtain controlling shares of Korean firms and to establish banking subsidiaries in Korea occurred in late 1997 and early 1998. Crossborder transactions rapidly increased thereafter, peaking at \$10 billion in 1999.

Table 2 shows the change in the extent of corporate control resulting from the M\&A transactions included in this paper. The columns of the table show the extent of ownership of the target prior to the acquisition, while the rows indicate post-acquisition ownership shares. The data show that in 842 out of 1011 transactions, the acquirer had no ownership stake in the target prior to the announcement. In 659 transactions $(490+$ $138+31$ ) or about $65 \%$ of the sample, the acquisition leads to a majority or near complete transfer of control to the acquirer. Note that in about $10 \%$ of the sample, the acquirer had majority ownership of the target prior to the acquisition.

Table 3 presents the transaction details for a sample of 62 US firms which engaged in M\&A activity in both developed and emerging markets. Panel A shows that the $66 \%$ of the total M\&A transactions are in the US as compared to $25 \%$ in other developed markets and $10 \%$ in emerging markets. Tender offers, although receiving 
significant attention in the domestic literature, are a small portion of the overall sample. Instead, it is three times more frequent for an emerging-market transaction to be privately negotiated. Method of payment data was not available for all observations. For observations with data, cash is the most common method of payment with all-cash acquisitions being six times more common than all-stock acquisitions. This pattern holds for targets in the United States, other developed markets, and emerging markets. Divestitures represent approximately $30 \%$ of the total sample with a higher proportion of spin-offs in the target regions outside of the US.

Panel B of Table 3 shows that the sample of mergers and acquisitions made by US firms domestically includes a wide range of deal values with a minimum transaction value of $\$ 0.75$ million and a maximum value of $\$ 65.59$ billion. The median transaction value is $\$ 100$ million. The median transaction values for targets in other developed and emerging markets are comparable to the domestic observations. The median transaction value for targets in developed markets other than the US is \$71.3 million and $\$ 73.1$ million for targets in emerging markets. Typically, for targets in the US or other developed markets, the average target stake acquired is $84.47 \%$ and $74.95 \%$, respectively. For targets in emerging markets, majority control is acquired in approximately half the observations, with an average control stake of 50.94\% being acquired.

\subsection{Measuring Returns}

The most statistically reliable evidence on whether M\&A activity creates value for shareholders comes from traditional event studies, where the average abnormal stock market reaction to a cross-border acquisition announcement is used to gauge the creation or destruction of value (Andrade, Mitchell, and Stafford, 2001). In efficient capital 
markets, stock prices adjust quickly to news of the acquisition and incorporate the acquisition's impact on expected changes in the value of the combined firm. At the announcement date, the combined firm values minus the pre-announcement stand-alone firm values reflect the market's assessment of the value creation or destruction resulting from the acquisition. To the extent that the real option of making an acquisition is embedded in the acquirer's stock price before the announcement is made, the returns on the announcement date suffer from attenuation bias.

This paper uses weekly stock price data to compute three different measures of returns for the acquirer and target firms, as well as the combined firm. The first measure is the raw buy-and-hold return over the relevant event window around the acquisition announcement. The second measure computes the raw returns minus the market returns over the event window. The third measure computes the cumulative abnormal return (CAR) over the event window using a market model as follows:

$$
R_{i t}=\alpha_{i}+\beta_{i} R_{m t}+\varepsilon_{i t}
$$

The coefficients $\alpha_{i}$ and $\beta_{i}$ are estimated for a given firm over a one-year interval starting eighteen months prior to the announced acquisition and ending six months before the announcement. The coefficients are then used to compute weekly expected returns around the acquisition announcement. The abnormal return is defined as the difference between the actual return and the expected return in the event window. Abnormal returns are cumulative, due to continuous compounding over the event window. The market returns used in the estimation are the broadest market index available for a particular country. For target firms, return data is dropped from sample if during the event window the target security did not change price for more than two consecutive weeks. Acquirer and target returns are calculated in terms of the local currency. Joint returns are based on 
returns in US dollars and a market-capitalization-weighted average of individual acquirer and target returns. The event window returns are standardized to monthly returns.

We report results for a three-week event window which includes the week before, the week of, and the week after the announcement. Since this paper focuses on targets in emerging stock markets where trading may be thin, the estimations were also repeated using a five-week event window starting two weeks before and ending two weeks after the acquisition. ${ }^{4}$

\section{How does the Stock Market React to Cross-border M\&A Transaction Announcements?}

If markets are efficient, changes in stock prices provide a summary statistic for changes in the fundamentals. To that extent, the responses of firms' stock prices to the announcement of an M\&A transaction reflect news about the present value of future cash flows. This section addresses the following question: Do acquisitions by foreign firms in emerging markets create value?

An acquisition can lead to a creation of value measured by joint returns if the cash flows of the merged firm are greater than the sum of its parts, namely, the cash flows of the two stand-alone firms. Table 4 displays the stock price reactions for the full sample of acquirers and targets as well as the joint returns for the combined firms. ${ }^{5}$ Joint announcement returns for acquirers and targets are positive and fairly similar across the different measures of returns and across the different event windows. Based on raw returns, joint returns range from $1.73 \%$ to $2.28 \%$, and are slightly smaller for market-

\footnotetext{
${ }^{4}$ The estimations were also conducted for acquirer firms with a three-day event window commonly used in the literature based on developed market returns which includes the day before, the day of, and the day after the announcement.

${ }^{5}$ The results include the stock price data for all acquirers and all targets, not just the sample of matched acquirer and target firms. The sample of acquiring firms is greater than the sample of target firms because of stock price data availability.
} 
adjusted returns, ranging from $1.08 \%$ to $1.79 \%$. The average combined market-adjusted announcement returns involving targets from East Asia is $2.34 \%$ and in Latin America is 0.86\%, although Latin American returns are not statistically significant.

\subsection{Joint Returns Increase When a Developed-Market Acquirer Gains Majority Control of an Emerging-Market Target}

In a world with incomplete contracts, the allocation of ownership within firms becomes important (Grossman and Hart, 1986). If the acquisition results in a transfer of control, it will shift the boundary of the acquiring firm and can alter the acquiring firm's incentives to transfer technology or invest in the target. The stock price reactions of the acquiring and target firms, when a cross-border acquisition leads to a majority control of the target firm by the foreign owner, capture the importance of acquiring control. The acquisition of majority control may be more important in countries with poor protection and enforcement of the minority shareholder rights (La Porta, Lopez-de- Silanes, Shliefer and Vishny, 1999).

If the transfer of control leads to an increase in investment and transfer of technology, joint returns should increase with control. The last panel of Table 4 displays average three-week announcement returns for a subsample of cross-border M\&A transactions where the developed-market acquirer gains majority control of the emergingmarket target. The magnitude of value creation increases when the acquirer gains majority control of the target in comparison to the results for the full sample in the first panel. The average joint acquirer and target announcement return is $5.89 \%$ in marketadjusted terms over the three-week window and is significantly higher statistically when compared to transactions where the acquirer does not gain majority control. 
The paper now turns to formal estimations to explore the hypothesis that the acquisition of majority control drives value creation in cross-border mergers and acquisitions.

\section{Does the Acquisition of Majority Control Drive Value Creation Through Cross- Border M\&A Transactions?}

The benchmark regression specification for examining the effects of acquisition characteristics on announcement returns is:

$$
R_{i t}=\alpha_{i}+\beta_{1} \cdot \text { MAJORITYCONTROL }_{i}+\gamma \sum_{j=1}^{n} \operatorname{CONTROLS}_{j}+\varepsilon_{i t}
$$

The left-hand side variable, $R_{i t}$, represents market-adjusted returns for the threeweek window that begins one week before and ends one week after the announcement of the acquisition. The intercept term, $\alpha_{i}$, measures the magnitude of the average announcement return over the three-week event window. MAJORITYCONTROL ${ }_{i}$ is a dummy variable that takes on a value of one if the acquirer owns a $50 \%$ or more share of the target following the acquisition and did not have control before. ${ }^{6}$

Table 5 presents the estimates for joint returns in the three-week window surrounding the cross-border acquisition announcement. Recall that estimating (2) without the majority control variable yields an estimate of the average change in joint returns surrounding an acquisition announcement. The coefficient estimate on the constant is 0.018 in Column $1 \mathrm{a}$ and is significant at the 5\% level. This indicates that joint returns increase significantly in the three-week announcement event window.

Column $1 \mathrm{~b}$ shows the results for the benchmark regression in (2). The magnitude of the coefficient on the MAJORITYCONTROL variable is 0.068 and is significant at the

\footnotetext{
${ }^{6}$ The regressions were also run including country-fixed effects. In general, country effects were insignificant.
} 
$1 \%$ level. The estimate suggests that the acquisition of majority control of the target drives joint returns up by $6.8 \%$ in the three-week event window surrounding the acquisition announcement. The coefficient on the constant term in Column 1a shows that, on average, joint returns increase by $1.8 \%$ when majority control is not included as an explanatory variable. Taking the difference in the coefficients, the result suggests that, conditional on acquiring majority control, average joint returns increase by $5 \%$ compared to the case when majority control is not acquired. Note that the constant term becomes insignificant after conditioning on acquiring majority control of the target.

The magnitude of the coefficient estimate on MAJORITYCONTROL ranges from 0.058 to 0.078 in the two regression specifications shown in Columns $1 \mathrm{c}$ and $1 \mathrm{~d}$ and is statistically significant at the $1 \%$ level in all specifications. Columns 1c and $1 \mathrm{~d}$ explore whether the existence of a prior relationship between the acquirer and the target firm has an impact on joint returns. The acquirer is classified as having a prior relationship with the target if the acquirer had an equity stake in the target prior to the acquisition announcement. The inclusion of the existence of a prior relationship by itself does not have a statistically significant impact on joint announcement period returns as seen in Column 1c.

Joint returns increase if the acquirer gains majority control after the acquisition, conditional on the existence of a prior relationship between the acquirer and the target (Column 1d). PRIOR RELATION*CONTROL captures the marginal effect of acquiring majority control conditional on the existence of a prior relationship between the acquirer and the target. The magnitude of this coefficient estimate is 0.07 , and it is statistically significant at the $10 \%$ level. Note that the raw effect of acquiring majority control is 0.058. The total effect is the sum of the coefficients for the raw and marginal effects. 
Thus, the total effect of acquiring majority control, conditional on the existence of a prior relationship between the acquirer and the target is $12.8 \%$ on joint returns.

Save for the acquisition of majority control, a whole host of other factors may also affect the creation of value through cross-border mergers and acquisitions. The estimations below explore alternative explanations that may be responsible for the positive announcement returns that accompany cross-border M\&A transactions.

\subsection{Alternative Explanations: Do Synergies Affect the Creation of Value?}

It is a common assumption that for both the acquirer and target firms to benefit from the synergies that accrue from an acquisition, the two firms must be related in some way (Bradley, Desai, and Kim, 1988). The two firms could be related because they are in the same industry, or through a vertical value chain. Since it is difficult to measure synergies directly the estimation procedure tests for the opposite case of diversifying transactions where it would be hard to make a case for the existence of synergies (Berger and Ofek, 1995). The estimation procedure includes an industry diversification variable to see whether returns are higher when the target and the acquiring firm are in the same two-digit industry.

The DIVERSIFY variable in Column 1e captures industrial diversification through the acquisition. The coefficient estimate is negative but statistically insignificant. The statistical insignificance of the coefficient estimate suggests that the acquisition of a target in an unrelated line of business does not affect joint returns in the acquisitionannouncement period. Out of 380 transactions where SIC code information was available for both the acquirer and the target, 129 transactions are classified as diversifying transactions. 
When examining the effects of M\&A activity in unrelated lines of business in the cross-border context, an additional case must be considered. Value creation in this case can be associated with the acquisition of a cash-starved emerging-market target by a cash-rich developed-market acquirer, regardless of industrial overlap. A high number of M\&A transactions between unrelated industries could in fact be a sign of cash-motivated mergers. If liquidity or cash is the main motivation for the acquisition, rather than technological synergies, the incidence of M\&A transactions in unrelated industries may increase during periods of financial crises. The provision of liquidity may have been an especially important factor during the Asian financial crisis, when firms were unable to borrow due to their high levels of dollar-denominated debt. In our sample 18 out of 58 observations that are recorded as having taken place during a crisis are diversifying transactions. To test the effect of liquidity-motivated sales by cash-strapped firms, the diversification dummy, DIVERSIFY, is interacted with a financial crisis dummy, CRISIS. The CRISIS dummy takes a value of one during a crisis and is zero otherwise. The effect is statistically insignificant.

\subsection{Alternative Explanations: Do Crisis Periods Affect the Creation of Value?}

The factors motivating an acquisition may change during periods of crisis. During periods of relative calm, cross-border M\&A activity can be attributed to factors such as the transfer of technology, synergies, vertical specialization, management externalities, differences in the cost of capital, and the acquisition of control. During

crisis periods the same factors may continue to drive cross-border M\&A activity. However, a number of additional factors, such as the presence of financially distressed or liquidity-constrained targets and increases in the bargaining power of the foreign 
acquirers, may also become important drivers of cross-border M\&A activity. If this is indeed true then crisis periods should coincide with greater joint acquirer and target gains.

A country-specific dummy for financial crisis, CRISIS, is included in Column $1 \mathrm{j}$ of Table 5 to see if the joint returns from an acquisition are systematically different during periods of financial turmoil in emerging markets. ${ }^{7}$ The point estimate for the CRISIS variable is statistically insignificant.

\subsection{Alternative Explanations: Do Changes in Regulations or Relative Bargaining Power Drive the Creation of Value?}

A number of factors could affect value creation and the distribution of gains between the acquirer and the target firm. Acquirer and target size are included in the estimations as possible indicators of firm bargaining power. Acquirer cash is included to pick up possible effects of liquidity provision for the target. Columns $1 \mathrm{f}$ and $1 \mathrm{~g}$ of Table 5 show that the point estimates for TARGET SIZE and ACQUIRER SIZE are statistically insignificant. Column $1 \mathrm{~h}$ shows that there is no significant statistical relationship between joint announcement returns and the amount of cash the acquirer has on hand. A caveat to bear in mind is that cash on hand does not provide an indication of the access to cash that the acquiring firm may have. ACQUIRER $C A S H$ in column $1 \mathrm{~h}$ provides a proxy, albeit an imperfect one, of the acquirer's access to cash. The effect of this variable on joint returns is statistically insignificant.

Columns $1 \mathrm{k}$ and 11 explore whether the acquirer or target being in the finance, insurance, or real estate sector affects joint returns. Dummies for the acquirer and target

\footnotetext{
7 The crises included are Mexico (1994), Thailand (1997), Malaysia (1997), Korea (1997), Indonesia (1997), Philippines (1997), Brazil (1999), and Argentina (2001). The crisis dummy takes a value of one from six months prior to the crisis to one year following the crisis.
} 
being in the FIRE sector are included to control for the possibility that the particular regulatory restrictions in that sector (on banks, in particular) may have a systematic effect on the returns to M\&A transactions. Again, the coefficient estimates for the ACQUIRER IN FIRE and TARGET IN FIRE dummies are statistically insignificant. Finally, the hypothesis that the regional location of the target affects joint announcement returns is explored in Column 1i. The coefficient for the TARGET IN ASIA variable is statistically insignificant suggesting that regional factors do not explain joint returns.

The coefficients on the interaction terms between the independent variables included in regression specifications $1 \mathrm{e}-11$ and the majority control variable are all insignificant. See Table 5 for details.

\subsection{Alternative Explanations: Do Deal Characteristics Drive the Creation of Value?}

The estimations were also run including various deal and target characteristics reported in the previous literature as determinants of joint returns. The additional variables tested include whether the target was bankrupt, there was a competing bidder, or an unsolicited bid, the target was a division, the deal was a new joint venture, the target was being privatized, the deal was privately negotiated, and whether the deal was a tender offer. None of these additional variables explain acquirer returns when an emerging-market target is acquired. A variable to capture the impact of the medium of payment was created as the fraction of cash paid in an acquisition relative to the total cash plus equity. The method of payment also proved insignificant in explaining joint returns.

In summary, the evidence from the formal panel estimations suggest that joint returns for the acquirers and targets increase significantly when a cross-border acquisition 
is announced. The increase in joint returns is linked to the acquisition of majority control of the target. Joint returns are also significantly related to the acquisition of majority control, conditional on the existence of a previous relationship between the acquirer and the target. These results are robust to the inclusion of a number of controls for acquirer and target characteristics.

\section{Shareholders of Both Developed Market Acquirers As Well As Emerging-Market Targets Gain from Cross-Border M\&A Transactions}

Based on US data, previous studies have found evidence of overall value creation through mergers and acquisitions (Andrade, Mitchell, and Stafford, 2001). Typically, joint returns tend to be positive, but following the Williams Act (1968), the lion's share of the joint gains accrue to target shareholders leaving little for the shareholders of the acquiring firms (Jensen and Ruback, 1983; Brickley, Jarrell, and Netter, 1988). This section provides evidence about the distribution of the joint gains that arise from crossborder M\&A transactions.

The first panel of Table 6A shows that shareholders of developed market firms reap significant gains when an emerging-market target is acquired. For the full sample of developed-market acquirers, the average announcement return in the event window that begins one week before and ends one week after the acquisition announcement ranges from $2.43 \%$ to $3.05 \%$ depending on the returns measure used.

The fact that acquiring firms realize positive returns when an acquisition is announced in an emerging market may suggest that developed-market acquirers have greater bargaining power relative to the emerging-market targets. Acquirers may have greater bargaining power, because fewer bidders compete for emerging-market targets, 
cash-strapped targets have liquidity needs, or changes in government policies help facilitate foreign M\&A transactions.

An alternative interpretation for the increase in acquirer returns may be asymmetric information between the acquirer and the target about the target's true fundamental value. In order for the target firm to negotiate the best possible offer, the target must be in a position to form an accurate estimate of its fundamental value. If the target is uncertain about its true stand-alone value, the firm may undervalue its assets. On the other hand, if acquirers are better able to assess the synergies from the merger, acquirers may be able to select and execute only those transactions that result in significant gains for them. The ability of acquirer firms to form a better estimate of the target's true value has particular significance in emerging markets where the stock price is often viewed as an especially noisy estimate of true firm values.

Announcement returns for target firms are also positive and statistically significant. In local currency terms, the average market-adjusted return for the target firm in the three-week event window ranges from $6.68 \%$ to $6.87 \%$. On average, M\&A transactions in emerging markets create value for acquirer as well as target firm shareholders.

Panels $\mathrm{B}$ and $\mathrm{C}$ in Table $6 \mathrm{~A}$ report the acquirer and target returns by region. In East Asia, acquirer gains range from $2.7 \%$ to $3.45 \%$ and are significant at the $5 \%$ level. Acquirer gains in Latin America are also positive, ranging from $1.89 \%$ to $2.23 \%$, and again are significant at the 5\% level. Targets also gain, especially in Latin America. In Asia, the target returns are 5.17\% and in Latin America target returns are 9.68\%.

Acquirers will also gain from M\&A transactions that achieve control of the target firm. This gain can be the result of the total gains being higher and the target and 
acquirer splitting these gains in a constant ratio. Alternatively, acquirers may pay a different price when they acquire control of the target.

The impact of the foreign acquirer gaining majority control on the target's stock price is less clear. On the one hand, if the market expects that the acquirer will transfer better technology and provide access to cheaper capital to the target, its stock price will increase. On the other hand if the foreign acquisition dilutes the ability of the previous owners to exercise private benefits of control, the target's stock price may fall or rise (Dyck and Zingales, 2004). Panel D in Table 6A shows that when the acquirer gains majority control of the target, the average monthly market-adjusted announcement return using a three-week event window is $3.99 \%$ for acquirer firms and $8.92 \%$ for target firms. Both acquirer and target returns increase with the acquisition of majority control.

Turning to the formal estimations, Table 7 presents the results for the acquisition announcement returns for acquirer firms. Column $2 \mathrm{a}$ shows that the coefficient for the average announcement returns for the acquirers is 0.024 and is significant at the $5 \%$ level. This estimate suggests that acquirer monthly abnormal returns increase by $2.4 \%$ in the three-week cross-border acquisition announcement window. This estimate corroborates the evidence presented using the raw data that, on average, cross-border M\&A transactions create value for developed-market acquirers when the target is in an emerging market.

The coefficient for MAJORITYCONTROL is 0.033 and is significant at the $5 \%$ level in Column $2 \mathrm{~b}$. The estimate suggests that acquirer returns rise by $3.3 \%$ if the acquirer gains majority control of the target. Column $2 \mathrm{~d}$ shows that the magnitude for the estimate for PRIOR RELATION*CONTROL is 0.06 . The estimate is significant at the $10 \%$ level. The estimate suggests that conditional on the existence of a prior relationship 
between the acquirer and the target, the acquisition announcement results in a $6 \%$ increase in acquirer returns if the acquisition results in majority control of the target.

The coefficient estimate for the DIVERSIFY variable in Table 7 (column 2e) is also negative and insignificant suggesting that the industrial diversification does not explain acquirer returns. The results in Columns $2 \mathrm{f}-21$ demonstrate a similar pattern to the results for joint returns in the three-week announcement window. After controlling for variables such as acquirer size, target size, acquirer cash, a crisis dummy, and whether the acquirer or the target are in the financial sector, the coefficient on MAJORITYCONTROL is significant in alternative regression specifications. According to the regression estimates, the increase in acquirer returns ranges from $3.1 \%$ to $4.6 \%$ in alternative specifications. The increase in acquirer returns, in turn, suggests that crossborder M\&A transactions in emerging markets create value for developed-market acquirers.

Table 8 shows the results for target returns. The constant term in Column 3a captures the average increase in target returns when a cross-border acquisition announcement is made. The magnitude of the coefficient is 0.069 and is significant at the $1 \%$ level. The estimate suggests that, on average, target returns increase by $6.9 \%$ when a cross-border acquisition is announced.

The results in Columns $3 \mathrm{~b}$ to $3 \mathrm{~d}$ suggest that when MAJORITYCONTROL is included in the regression specification, the intercept term is positive but statistically significant in only one instance. Moreover, there is no statistical relationship between target returns and the acquisition of majority control by the developed-market acquirer. The coefficient on MAJORITYCONTROL is not statistically significant in any specification. It appears that target returns cannot be explained by the acquisition of 
majority control by the acquirer. However, given the small sample size and the fact that emerging-market returns are measured with greater noise, the lack of statistical significance should be interpreted with caution.

The regression specifications in Columns $3 \mathrm{a}$ to $3 \mathrm{~d}$ were also run without including MAJORITYCONTROL as an explanatory variable on the right hand side. The intercept term is statistically significant in all specifications at the $1 \%$ or $5 \%$ levels. The magnitude of the coefficient on the intercept term ranges from 0.031 to 0.069 in alternative regression specifications. The evidence suggests that, on average, target returns increase from $3.4 \%$ to $9.6 \%$ in the three-week announcement window surrounding the cross-border acquisition announcement.

To get a sense of the magnitude of the wealth creation from a typical acquisition, the Table $6 \mathrm{~b}$ shows the median and average market returns and market capitalization figures for acquirers and target firms. The median equity market value for the developed market acquirer firms in the sample is $\$ 12.91$ billion. Also in Panel $\mathrm{A}$, the $0.91 \%$ median market adjusted return corresponds to a $\$ 117.17$ million market capitalization gain for acquirer firm shareholders over the three week window in the full sample.

The average market-adjusted return for acquirers in transactions where control is acquired is $4.06 \%$ compared with an average acquirer return of $0.47 \%$ when control is not required. A Wilcox-signed-rank test of medians also shows that acquirer returns are significantly higher in transactions where the acquirer gains majority control of the target in comparison to transactions where majority control is not acquired $(p=0.008)$. In transactions where the acquirer gains majority control, the median acquirer return of $3.97 \%$ corresponds to a median market-capitalization gain of $\$ 512.1$ million-the acquirer value gains are four times higher than the full sample (Panel B). Panel C shows 
that the median acquirer return in transactions where majority control is not acquired is $0.42 \%$ and leads to median market capitalization gain of $\$ 54$ million. $^{8}$

The median equity market value for an emerging-market target in Table $6 \mathrm{~B}$ is \$201.6 million. For the full sample, a 1.55\% median market-adjusted return corresponds to a $\$ 3.12$ million increase in the market capitalization value for target firm shareholders over the three week event window. The Wilcox-signed-rank test shows that the median target returns are not significantly different in transactions where the acquirer gains majority control $(p=0.367)$. In transactions where the acquirer gains majority control, the median market capitalization gain for target firm shareholders is $\$ 1.69$ million and $\$ 2.83$ million in transactions where the acquirer does not gain majority control. The evidence from the back-of-the-envelope value gain calculations in Table 6B suggest that, distinct from domestic transactions, the distribution of gains from cross-border M\&A transactions shifts in favor of acquirer firms.

\section{Do Foreign Acquirers Take Advantage of Emerging-Market Targets? Revisiting Value Creation During Crisis Periods}

If the bargaining power of foreign acquirers increases during crises, the distribution of the value gains may change in favor of the acquirers. Alternatively, the price that acquirers pay for the target during a crisis may be different compared to periods of financial calm. Crisis periods generally result in a collapse in beliefs about future payoffs in the emerging stock markets. If these beliefs are not rational and acquirers have greater confidence in the fundamentals, acquirers may realize further gains during times

\footnotetext{
${ }^{8}$ The value gains were also estimated on a transaction by transaction basis. The median market capitalization gain is $\$ 309.03$ million in transactions which result in a transfer of majority control to the acquirer compared with $\$ 0.99$ million in transactions that do not result in a transfer of majority control.
} 
of crisis. The identification strategy employed in this paper allows for the following test of whether the acquirers paid different prices for the targets during a crisis. Acquirer returns in crisis periods should be higher than in non-crisis periods, if targets are acquired at bargain prices during a crisis.

Table 9 displays the results for the acquirers. Columns 1a to $3 \mathrm{a}$ show that acquirer returns in the pre-crisis, crisis, and post-crisis periods. Note that the time dummy for the early, pre-crisis period (1988-1995) is negative and significant. However, the time dummy for the middle period (1997-1999) in Column 1b which coincides with the Asian crisis is statistically insignificant. The data suggest that acquirer returns did not increase during the crisis. The time dummy for the post-Asian-crisis period (2000-2003) in Column 3a of Table 9, on the other hand, is significantly positive. Moreover, when MAJORITY CONTROL is included in the regression specifications in Columns 4a to 6a, the coefficient estimates on the time dummies are no longer significant. The coefficient estimate for MAJORITY CONTROL is positive and significant at the 5\% level. At first pass, the effect of acquiring majority control appears to be invariant to the state of the financial markets in Panel A. The estimations in Panel B explore the impact of financial crisis on the returns to acquirers and targets in greater detail below.

Sovereign bond spreads can be used as a measure for the cost of capital in emerging markets. As a robustness check, the estimates include the relative value of the JP Morgan Emerging Market's Bond Index (EMBI) spread as an explanatory variable. Column $1 \mathrm{~b}$ in Panel B of Table 9 shows that the coefficient estimate for the EMBI spread is positive and significant - as sovereign spreads widen, acquirer returns increase. The result suggests that acquirer returns increase as the cost of capital increases in emerging markets. 
Note that the cost of capital is likely to increase further in emerging markets during financial crises. The regression specification in Column $2 b$ of Table 9 includes the effect of the EMBI spread conditional on there being a crisis in the emerging market. While the raw effect of the EMBI spread remains positive and significant in explaining announcement returns for acquirers, the coefficient on the interaction term between the spread and crisis, EMBI*CRISIS, is statistically insignificant. The result suggests that the effect of EMBI spreads on acquirer returns does not appear to change during crisis periods. The evidence, therefore, does not confirm that targets were being acquired at bargain prices during the crisis.

Finally, Column $3 \mathrm{~b}$ examines the effect of acquiring majority control conditional on the cost of capital as measured by the EMBI spread. While the coefficient estimate for MAJORITY CONTROL is positive and significant, the effect of acquiring control conditional on the EMBI spread (EMBI*CONTROL) is statistically insignificant. Similarly, the coefficient estimate on EMBI*CRISIS*CONTROL in Column $4 \mathrm{~b}$ is also statistically insignificant. The two sets of results suggest that the impact of acquiring control on acquirer returns is not significantly different between crisis and non crisis periods.

\section{Selection Bias: Do the Acquirers in the Sample Experience Positive Announcement Returns When They Acquire Developed Market Targets?}

The results reported thus far suggest that there are significant gains to acquirers from emerging-market M\&A transactions. Although the estimations include controls for a number of factors, the results may largely be driven by acquirer-firm characteristics that have little to do with the particular circumstances in emerging markets. For example, 
note that the median size of a developed market acquirer in the sample is $\$ 12.91$ billion, more than 60 times larger than the median emerging-market target.

It is possible that large firms have greater bargaining power or an informational advantage in making acquisitions in general and not in emerging markets in particular. The following questions arise in this context. Are the gains to acquirers specific to emerging-market acquisitions? Or, do the acquirer firms in the sample reap gains even when they make acquisitions in developed markets? If the acquirer-firm returns increase when they announce an acquisition regardless of whether it is in an emerging or a developed market, then a sample selection bias in the form of acquirer characteristics may be driving the results in this paper. However, if the acquirer-firm returns increase only when they acquire an emerging-market target, then the appropriate interpretation of the increase in acquirer returns may be that the acquisition of control in emerging markets, in particular, is driving the result.

To test whether majority control matters outright or only in situations where institutions are poor, the announcement returns for developed-market acquirers are compared between developed- and emerging-market M\&A transactions. The sample is extended to include the acquisitions made by developed-market acquirers in France, Germany, Japan, United Kingdom, United States, Italy, Spain, Hong Kong, and Singapore in addition to the emerging-market acquisitions.

Table 10 presents the results. Column 1a shows that in the full set of targets, acquirers now experience negative but statistically insignificant returns in the three-week event window. The results in Column $1 \mathrm{~b}$ show that when a dummy variable for an emerging-market target is introduced into the regression specification, developed-market acquirers experience positive and statistically significant returns of 3.3\% in the three- 
week event windows. Taken together, the results in Column 1a and $1 \mathrm{~b}$ suggest that shareholder wealth effects for developed-market acquirers are positive only when an acquisition is made in an emerging market and not in developed markets.

Column 1c shows that while the coefficient on the emerging-market-target dummy variable has a magnitude of 0.033 and continues to be significant when the acquisition of MAJORITY CONTROL is introduced as an explanatory variable on the right-hand side. However, the coefficient on the MAJORITY CONTROL is negative and statistically insignificant suggesting, when developed-market targets are pooled together with emerging-market targets, the acquisition of control per se does not result in positive returns for developed-market acquirers.

In column 1d, MAJORITY CONTROL is interacted with the emerging markets dummy variable. The coefficient on MAJORITYCONTROL*EMERGING MARKET TARGET is 0.075 and is significant at the 5\% level. The result suggests that conditional on the target being in an emerging market, the acquisition of majority control results in positive returns for developed-market acquirers. Note that the total effect of acquiring an emerging-market target on developed-market-acquirer returns is the sum of the coefficients on the raw effects of the EMERGING MARKET TARGET dummy variable and the MAJORITY CONTROL dummy variable and the condition effect of MAJORITY CONTROL*EMERGING MARKET TARGET which is equal to 0.056. The sum of the coefficients suggests that, on average, developed-market-acquirer returns increase by $5.6 \%$ when majority control is acquired in an emerging-market target.

Columns $1 \mathrm{e}$ and $1 \mathrm{f}$ suggest that the acquisition of majority control leads to a positive and significant increase in acquirer returns when the regression specification includes a proxy for whether or not the acquirer had a relationship with the target firm 
before the acquisition was announced. The results show that the coefficient on MAJORITYCONTROL*EMERGING MARKET TARGET is 0.075 and 0.074 in the two columns, respectively, and is significant at the 5\% level. In contrast to the results in section 4, the acquisition of control in an emerging-market target for an acquirer that had a previous relationship with the target does not explain the increase in acquirer returns when a cross-border acquisition is announced. The coefficients PREVIOUS RELATIONSHIP and PREVIOUS RELATIONSHIP*EMERGING MARKET TARGET are statistically insignificant.

The coefficient on MAJORITYCONTROL ${ }^{*} E M E R G I N G$ MARKET TARGET is 0.075 and 0.077 in Columns $1 \mathrm{~g}$ and $1 \mathrm{~h}$ and is significant at the $5 \%$ level. The two regression specifications also show that the impact on acquirer returns is negative and insignificant when US acquirers make unrelated acquisitions. The coefficient on DIVERSIFY and the coefficient on DIVERSIFY*EMERGING MARKET TARGET are both negative but not statistically significant. The acquisition of majority control in the emerging-market target leads to a 7.5\%-7.7\% increase in acquirer returns when a crossborder acquisition is announced even with the inclusion of industrial diversification as an explanatory variable on the right-hand side.

Finally, Columns $1 \mathrm{i}$ and $1 \mathrm{j}$ examine whether the deal size has any explanatory power for US-acquirer announcement returns. In both regression specifications, the value of the transaction has a positive but insignificant effect on acquirer returns. The coefficient on MAJORITY CONTROL*EMERGING MARKET TARGET is 0.129 in the both columns and is significant at the $10 \%$ level.

In summary, the results in this section suggest that when the sample of crossborder M\&A transactions announced by US acquirers in emerging markets is extended to 
include M\&A transactions in other developed markets, acquirer returns increase significantly only when the acquisition of an emerging-market target is announced. The evidence therefore suggests that the increase in acquirer returns is not being driven by acquirer characteristics. Rather, the acquisition of majority control of an emergingmarket target is the primary driver of acquirer returns when a cross-border acquisition is announced. One explanation for the result that the acquisition of majority control appears to matter only in emerging markets is that the transfer of majority control may provide a mechanism through which acquirers are able to lend developed-market institutions in the form of improved property rights to emerging-market targets (Acemoglu and Johnson, 2003; Bris and Cabolis, 2004).

\section{Do Industry Characteristics Drive the Importance of Acquiring Majority Control in Emerging Markets?}

\subsection{Does the R\&D Intensity in the Target Firm's Industry Matter?}

To investigate the factors that drive the importance of acquiring majority control, a number of alternative hypotheses are considered. First, in the absence of control, weak institutions and legal environments in emerging markets may inhibit acquiring firms from making technology transfers to the target firms. If acquiring firms hold back from transferring technology in emerging-market transactions which do not involve control, the impact of this effect should be the most acute in R\&D-intensive industries. Since patent and legal protection matter in R\&D-intensive industries, the prediction is that the stock market's reaction to transactions where control is acquired will be directly proportionate to the R\&D intensity of an industry.

To test the prediction that the $\mathrm{R} \& \mathrm{D}$ intensity of an industry matters, the paper constructs a metric of R\&D intensity using US data. Using all US firms in Compustat 
from 1990 to 2002 the research and development expense (Compustat data item \#46) is divided by net sales (Compustat data item \#12). Dividing by net sales normalizes the R\&D expenses by the size of the firm. This measure is sorted by 2-digit SIC codes and an average measure of $\mathrm{R} \& \mathrm{D}$ intensity by 2 -digit SIC code is constructed. The measure of R\&D intensity is then matched by industry with the 2-digit SIC code of the emergingmarket targets.

The findings are as follows. Table 11 shows that the raw effect of the acquisition of control in an emerging-market target is positive and significant in alternative specifications. In column 3, the marginal effect of control conditional on the level of R\&D intensity is also positive and significant at the $1 \%$ level. The sum of the coefficients on CONTROL and CONTROL*RDINTENSITY provides a measure of the total effect of control and R\&D intensity on acquirer returns. The sum of the two coefficients is 0.43 and suggests that acquirer returns increase by $4.3 \%$ when control is acquired in an R\&D-intensive industry.

It is worth noting that the RDINTENSITY measure also predicts whether control is acquired in any given transaction. For example, compare a target, say, an electric power plant, with an average $R \& D$ intensity of 0.148 with a target which manufactures automobiles with an R\&D intensity of 0.324 . Logit regression estimates with control as a right-hand side variable suggest the difference in the R\&D intensity of the two industries predicts a $16 \%$ increase in the probability that control is acquired in the transaction. The result is statistically significant at the $5 \%$ level.

If it is the case that weak legal settings in emerging markets drives the importance of acquiring control, the effect should not be evident in developed markets. When the estimations are run by pooling developed- and emerging-market targets, the results show 
that the acquisition of control conditional on $R \& D$ intensity appears to matter only when the target is located in an emerging market. Column 6 of Table 11 shows that the acquisition of control conditional on R\&D intensity is positive and significant when the transaction involves an emerging-market target. The coefficient on EMTARGET*CONTROL ${ }^{*} R D I N T E N S I T Y$ is 0.044 and is significant at the $1 \%$ level. On the other hand, the coefficient on CONTROL $*$ RDINTENSITY which does not condition on the target being in an emerging market is negative and significant.

R\&D-intensive industries such as information technology and pharmaceuticals experienced very high returns in the late 1990s. There is a concern, therefore, that the result of $R \& D$ intensity as a key determinant of acquirer returns is merely picking up the boom-time returns in these industries. As a final robustness check for the result that R\&D intensity matters in explaining acquirer returns in emerging markets, additional estimations were conducted by using industry-adjusted returns on the left-hand side. The results remain qualitatively similar. The coefficient estimate for CONTROL $*$ RDINTENSITY when the target is in an emerging market remains positive and significant.

\subsection{Does the Dependence on External Finance, Investment Intensity, or Fixed Assets in the Target Firm's Industry Matter?}

A second hypothesis may be that foreign acquirers are more likely to provide access to external-capital markets to emerging-market targets if they own a majority stake in these firms. A measure of the dependence on external capital, EXCAP, in an industry is adapted from Rajan and Zingales (1998) as follows. Using all US firms in Compustat from 1990 to 2002, we calculated their annual capital expenditures minus cash flow from operations divided by their capital expenditures. Cash flow from operations is defined as 
operating income before depreciation plus decreases in inventories plus decrease in receivables plus increase in payables. An industry level average measure is constructed by 2-digit SIC code, and these results are matched to the 2-digit SIC code of the emerging-market targets. The measure is designed to capture an industry's dependence on external finance and whether this dependence makes an acquiring firm more likely to acquire control. However, the estimations do not bear out this hypothesis. The coefficient on the EXCAP measure interacted with the MAJORITY CONTROL does not explain the positive returns to acquiring firms when an emerging-market M\&A transaction is announced.

The third hypothesis for why majority control matters may be related to the degree of investment intensity in an industry. A measure of investment intensity, INVMEASURE, is calculated by dividing capital expenditures by net sales for any given firm in Compustat from 1990-2002. Capital expenditures are normalized by sales to be consistent with the R\&D measure. Industry-level averages are constructed by using the firm-level measures and matched with the 2-digit SIC codes of the emerging-market targets. Once again, the measure of investment intensity does not explain the positive acquirer returns when majority control of the emerging-market target is acquired.

The final hypothesis for why majority control may matter is that foreign acquirers may be more likely to transfer fixed assets when they have majority control of the emerging-market target. To explore this hypothesis, FASSETMEASURE is constructed by dividing net property plant and equipment by net sales for all firms in Compustat from 1990-2002. Industry-level averages were matched to emerging-market-target 2-digit SIC codes. The coefficient on the FASSETMEASURE interacted with the MAJORITY 
CONTROL ${ }^{*} E M T A R G E T$ is positive and significant. However, this result holds for only the US acquirers in the sample.

\section{Conclusion}

There has been considerable debate about the welfare effects of the boom in cross-border M\&A transactions in emerging markets. At the root of this debate is the question of whether cross-border mergers and acquisitions result in a creation of value through the transfer of corporate ownership from domestic to foreign investors and the distribution of the potential gains from the acquisition between shareholders of target and acquiring firms. This paper uses the stock-price reaction of acquiring and target firms to the announcement of an acquisition as a summary statistic for value creation through foreign M\&A transactions. The acquirer and target firms' stock price reaction to the announcement of an acquisition reveals information about (i) the potential wealth creation from the merger and (ii) how the gains and losses from an acquisition are assigned to the acquiring and target firms. The stock market's reaction to the information contained in the acquisition announcement reveals the market's view of the transaction.

The paper examines all transactions involving a developed-country acquirer and an emerging-market target between January 1, 1988 and December 31, 2002 for which stock-price data are available. In general, the results from panel data estimations suggest that the stock market anticipates significant value creation from the merger for the target and the acquiring firms. Joint monthly returns based on market-capitalization weighted returns in dollars increase by $1.8 \%$ when a cross-border acquisition is announced. The benchmark results indicate that target firms benefit from the acquisition, experiencing average monthly returns of $6.69 \%$. Both sets of results are consistent with the findings in 
the literature on domestic mergers and acquisitions. In contrast to the previous literature that uses US data, the evidence suggests that acquirer returns also show a statistically significant increase of $2.4 \%$.

The benefits from the acquisition stem from the transfer of majority control from the emerging-market target to the developed-market acquirer. The paper also compares acquirer returns for US firms when the acquisition is announced in a developed-market rather than in an emerging market. The data suggest that positive acquirer returns are specific to M\&A transactions in emerging markets, and that gaining corporate control is the key feature of transactions that deliver positive returns. Joint return increases range from $5.8 \%$ to $7.8 \%$ when majority control is acquired. Overall, the results in the paper suggest that the boom in foreign direct investment flows to emerging markets in the 1990s led to a transfer of control to foreign acquirers and substantial gains to shareholders of both the acquiring and the target firms. 


\section{References}

Acemoglu, Daron and Simon H. Johnson (2003). "Unbundling Institutions." MIT Department of Economics Working Paper No. 03-29.

Aitken, Brian J. and Ann E. Harrison (1999). "Do Domestic Firms Benefit from Direct Foreign Investment? Evidence from Venezuela." American Economic Review, Vol. 89, 605618 .

Alchian, Armen, Robert Crawford, and Benjiman Klien (1978). "Vertical Integration, Appropriable Rents, and the Competitive Contracting Process." Journal of Law and Economics, Vol. 21, No. 2, 297-326.

Andrade, Gregor, Mark L. Mitchell, and Erik Stafford (2001). "New Evidence and Perspectives on Mergers.” Journal of Economic Perspectives, Vol. 15, No. 2, 103-120.

Antras, Pol (2003). "Firms, Contracts, and Trade Structure." Quarterly Journal of Economics, Vol. 118, No. 4, 1375-1418.

Barber, Brad, Richard Lyon and Chih-Ling Tsai (1999). "Improved Methods for Tests of LongRun Abnormal Performance.” Journal of Finance, Vol. 54, No. 1, 165-201.

Berger, Philip and Eli Ofek (1995). “Diversification's Effect on Firm Value.” Journal of Finacial Economics, Vol. 37, No.1, 39-66.

Bradley, Michael, Anand Desai, and E. Han Kim (1988). "Synergistic Gains from Corporate Acquisitions and their Division Between the Stockholders of Target and Acquiring Firms." Journal of Financial Economics, Vol. 21, No. 1, 3-40.

Brickley, James, Gregg Jarrell, and Jeffrey Netter (1988). "The Market for Corporate Control: The Empirical Evidence Since 1980." Journal of Economic Perspectives, Vol. 2, No. 1 49-68.

Bris, Arturo and Christos Cabolis (2004). "Adopting Better Corporate Governance: Evidence from Cross-Border Mergers.” Mimeo, Yale School of Management.

Caves, Richard E. (1996). Multinational Enterprise and Economic Analysis. 2nd Edition, Cambridge University Press.

Coase, Ronald (1937). "The Nature of the Firm." Economica, Vol. 4, No. 16, 386-405.

Dyck, Alexander and Luigi Zingales (2004). "The Private Benefits of Control." Journal of Finance, Vol. 59, No. 2, 533-596.

Froot, Kenneth (1991). "Japanese Foreign Direct Investment," in U.S.-Japan Economic Forum, Vol. 1, M. Feldstein and Y. Kosai, eds., National Bureau of Economic Research and Japan Center for Economic Research. 
Froot, Kenneth and Jeremy Stein (1991). "Exchange Rates and Foreign DirectInvestment: An Imperfect Capital Markets Approach.” Quarterly Journal of Economics, Vol. 106, No. 4, 1191-217.

Grossman, Sanford and Oliver Hart (1986). "The Costs and Benefits of Ownership: A Theory of Vertical and Lateral Integration." The Journal of Political Economy, Vol. 94, No. 4, pp. 691-719.

Jensen, Michael and Richard Ruback (1983). "The Market for Corporate Control: The Scientific Evidence." Journal of Financial Economics, Vol. 11, No. 1, 5-50.

Kindleberger, Charles (1969). American Business Abroad: Six Lectures on Direct Investment. New Haven. Yale University Press.

Krugman, Paul (1998). "Firesale FDI." MIT Working Paper.

La Porta, Rafael, Florencio López-de-Silanes, Andrei Shleifer, and Robert Vishny (1998). "Law and Finance.” Journal of Political Economy, Vol. 106, No. 6, 1113-1155.

Lang, Larry and Rene Stulz (1994), “Tobin's q, Corporate Diversification and Firm

Performance.” Journal of Political Economy, Vol. 102, No. 6, 1248-1280.

Moeller, Sara B., Frederik P. Schlingemann, and Rene M. Stulz (2004). "Wealth Destruction on a Massive Scale? A Study of Acquiring-Firm Returns in the Recent Merger Wave." Journal of Finance, Forthcoming.

Perez-Gonzales, Francisco (2004). "The Impact of Acquiring Control on Productivity: Evidence from Mexican Manufacturing Plants." Working Paper, Columbia University.

Rajan, Raghuram G. and Luigi Zingales (1998). "Financial Dependence and Growth." American Economic Review, Vol. 88, No. 3, 559-586.

Williamson, Oliver E. (1979). "Transaction Cost Economics: The Governance of Contractual Relations." Journal of Law and Economics, Vol. 22, No. 2, 233-261. 
Figure 1: As a Fraction of FDI, Cross Border M\&As increase in the 1990s

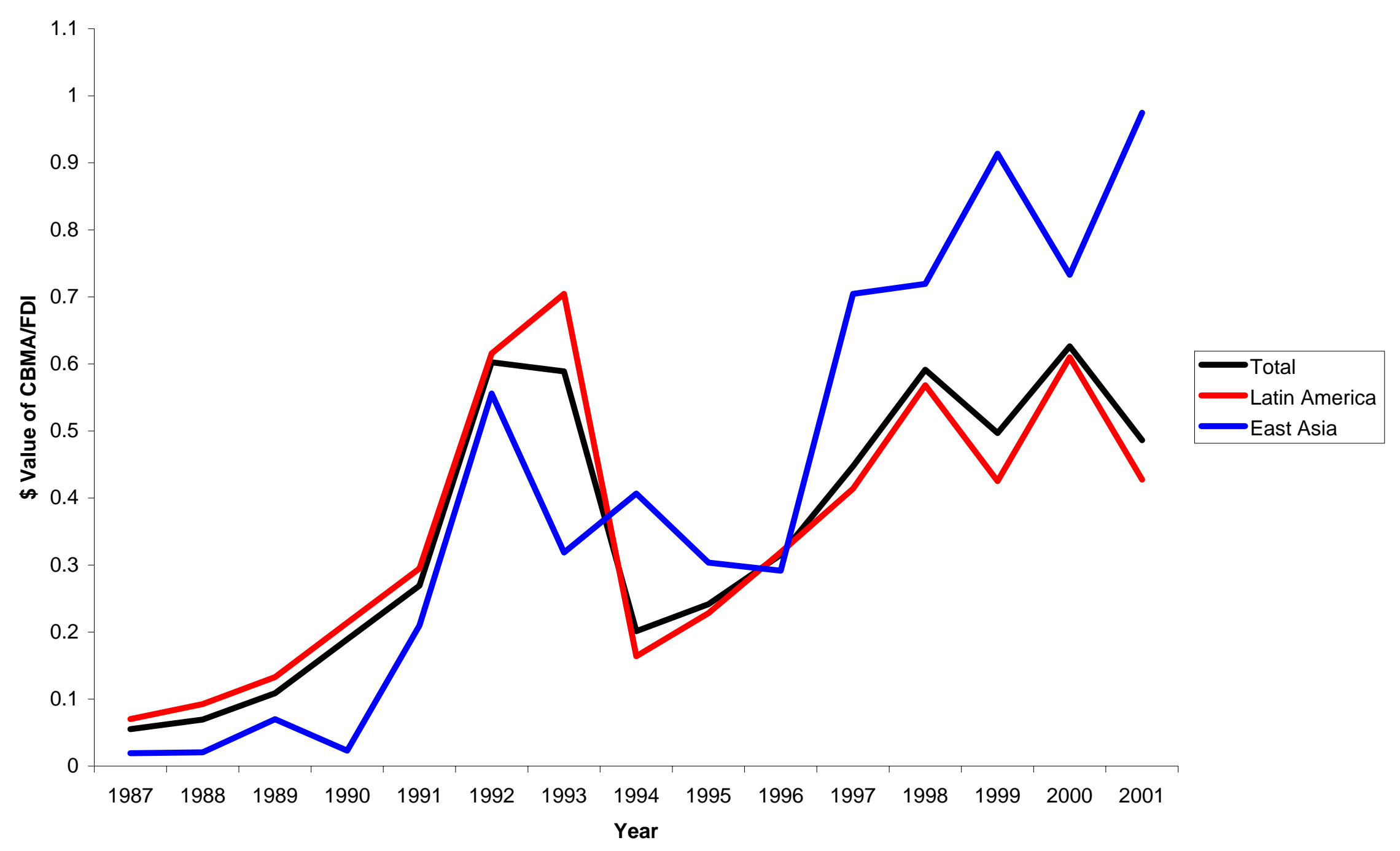


Figure 2a: Deregulation of Foreign Ownership Restrictions Facilitates the Increase in Cross-Border M\&A Activity.

Thailand: Value of Cross-Border M\&A (US\$ millions)

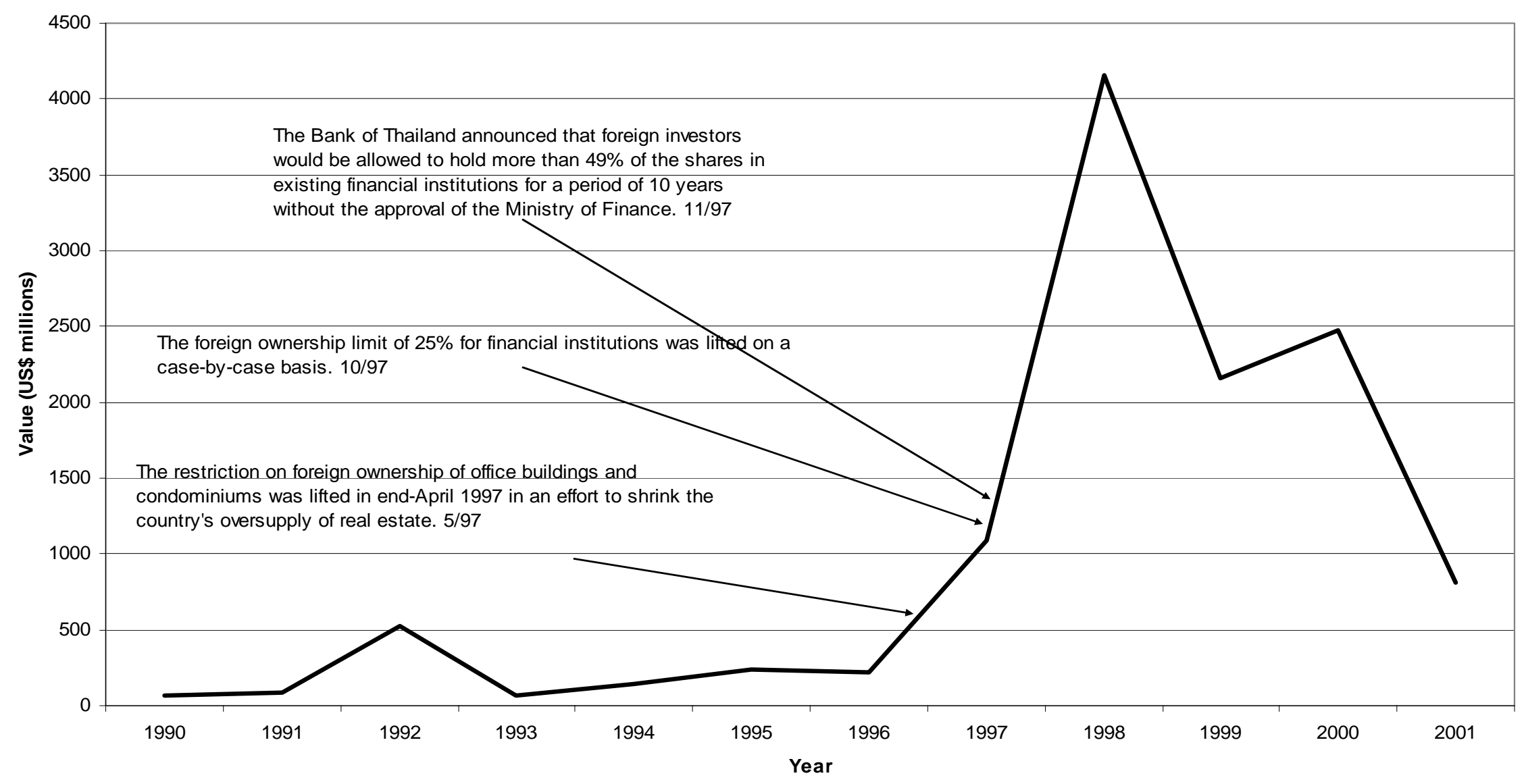


Figure 2b: Deregulation of Foreign Ownership Restrictions Facilitates the Increase in Cross-Border M\&A Activity.

South Korea: Value of Cross-Border M\&A (US\$ millions)

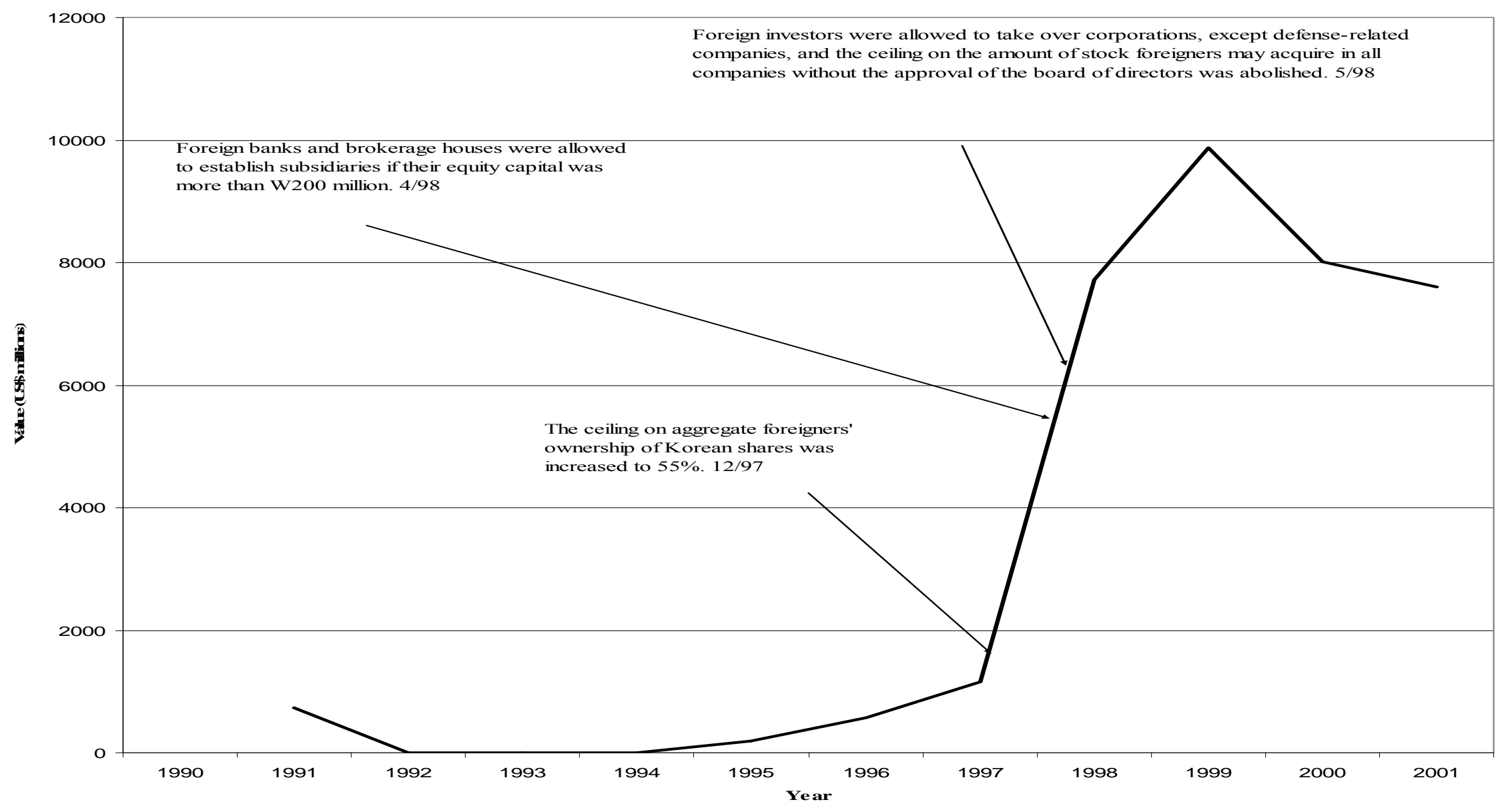


Table 1. The Frequency of Cross-Border M\&A Transactions in Emerging Markets Varies by Time, Region, and Sector.

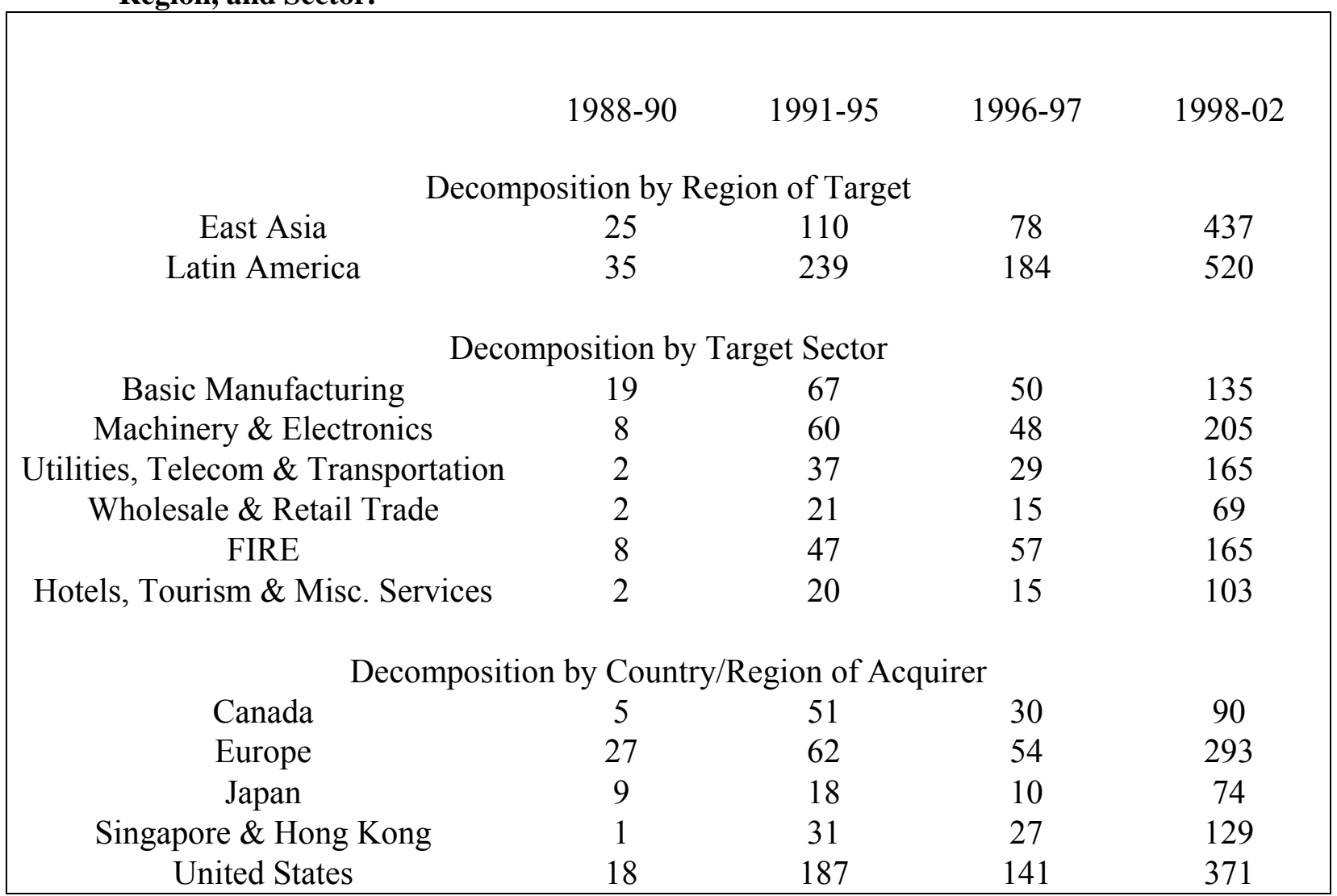

Notes: The table summarizes all cross-border mergers and acquisitions involving a public acquirer from a developed market and a public target from a developing market by region, by sector, and over time for all cross-border M\&A transactions which were announced between 1988 and 2002. The emerging markets include Argentina, Brazil, Chile, Indonesia, Malaysia, Mexico, Philippines, South Korea, and Thailand. The developed markets include Canada, France, Germany, Hong Kong, Italy, Japan, Netherlands, Singapore, Spain, the United Kingdom, and the United States. Basic manufacturing is targets with 2-digit SIC codes 20-29; Machinery \& Electronics is targets in SIC codes 30-39; Utilities, Telecom and Transportation is targets in SIC codes 40-49; Wholesale and Retail Trade is targets in SIC codes 50-59; FIRE is targets in SIC codes 60-69; Hotels, Tourism and Miscellaneous services is targets in SIC codes 70-89. Data for M\&A transactions, primary SIC codes, and target and acquirer nations is from SDC. 
Table 2. There Is Cross Sectional Variation in Post Acquisition Ownership through Cross-Border Mergers and Acquisitions.

\begin{tabular}{|c|c|c|c|c|c|c|}
\hline \multirow{2}{*}{$\begin{array}{c}\text { Number of M\&A } \\
\text { transactions }\end{array}$} & \multicolumn{2}{|c|}{$\begin{array}{l}\text { Acquirer had } \\
\text { Minority } \\
\text { Interest Before } \\
\text { Acquisition }\end{array}$} & \multicolumn{4}{|c|}{ Pre-Acquisition Ownership } \\
\hline & No & Yes & $<20 \%$ & $20-40 \%$ & $40-50 \%$ & $50 \%+$ \\
\hline $0-50 \%$ & 214 & 16 & 8 & 6 & 2 & 0 \\
\hline $51-95 \%$ & 138 & 47 & 5 & 9 & 5 & 28 \\
\hline $95-100 \%$ & 490 & 106 & 1 & 3 & 8 & 94 \\
\hline
\end{tabular}

Notes: The table summarizes cross-border mergers and acquisitions involving a public acquirer from a developed market and a public target from an emerging market by pre- and post-acquisition ownership. The table covers all M\&A transactions announced between 1988 and 2002 and for which control data is available. Emerging markets include Argentina, Brazil, Chile, Indonesia, Malaysia, Mexico, Philippines, South Korea, and Thailand. Developed markets include Canada, France, Germany, Hong Kong, Italy, Japan, Netherlands, Singapore, Spain, the United Kingdom, and the United States. M\&A transactions are identified and control information is collected from SDC data items "Percent Shares Acquired" and "Percent Shares Owned After Transaction." Control information is available for 1011 observations. 
Table 3. There Is Cross Sectional Variation in Cross-Border M\&A Transaction Characteristics.

\begin{tabular}{|c|c|c|c|c|c|}
\hline \multicolumn{6}{|c|}{ Panel A } \\
\hline Transaction Characteristics & $\begin{array}{l}\text { Targets in } \\
\text { the United } \\
\text { States }\end{array}$ & \multicolumn{2}{|c|}{$\begin{array}{l}\text { Targets from other } \\
\text { Developed Markets }\end{array}$} & \multicolumn{2}{|c|}{$\begin{array}{c}\text { Targets from Emerging } \\
\text { Markets }\end{array}$} \\
\hline Total M\&A transactions & 836 & \multicolumn{2}{|c|}{314} & \multicolumn{2}{|r|}{124} \\
\hline Tender offer & 33 & \multicolumn{2}{|c|}{7} & \multicolumn{2}{|r|}{9} \\
\hline All-cash payment & 257 & \multicolumn{2}{|c|}{102} & \multicolumn{2}{|r|}{65} \\
\hline All-stock payment & 59 & \multicolumn{2}{|c|}{7} & \multicolumn{2}{|r|}{2} \\
\hline $\begin{array}{l}\text { Payment mix of cash and } \\
\text { stock }\end{array}$ & 18 & \multicolumn{2}{|r|}{2} & \multicolumn{2}{|r|}{1} \\
\hline Target being privatized & 2 & \multicolumn{2}{|c|}{6} & \multicolumn{2}{|r|}{2} \\
\hline $\begin{array}{l}\text { Acquisition privately } \\
\text { negotiated }\end{array}$ & 107 & \multicolumn{2}{|c|}{35} & \multicolumn{2}{|r|}{22} \\
\hline Target bankrupt & 5 & \multicolumn{2}{|c|}{8} & \multicolumn{2}{|r|}{1} \\
\hline Target being divested & 218 & \multicolumn{2}{|c|}{119} & \multicolumn{2}{|r|}{44} \\
\hline Joint Venture & 2 & \multicolumn{2}{|c|}{2} & \multicolumn{2}{|r|}{5} \\
\hline \multicolumn{6}{|c|}{ Panel B } \\
\hline & Mean & Median & Minimum & Maximum & $\begin{array}{c}\text { Percent of } \\
\text { Sample with } \\
\text { Reported Data }\end{array}$ \\
\hline \multicolumn{6}{|c|}{ Transaction Value } \\
\hline Targets in US & $\$ 1.24 \mathrm{~B}$ & $\$ 100 \mathrm{M}$ & $\$ 0.75 \mathrm{M}$ & $\$ 62.59 \mathrm{~B}$ & $44.4 \%$ \\
\hline $\begin{array}{l}\text { Other developed market } \\
\text { targets }\end{array}$ & $\$ 355.7 \mathrm{M}$ & $\$ 71.3 \mathrm{M}$ & $\$ 0.47 \mathrm{M}$ & $\$ 5.25 \mathrm{~B}$ & $38.2 \%$ \\
\hline Emerging-market targets & $\$ 216.4$ & $\$ 73.1 \mathrm{M}$ & $\$ 0.05 \mathrm{M}$ & $\$ 3.204 \mathrm{~B}$ & $60.4 \%$ \\
\hline \multicolumn{6}{|c|}{ Target Stake Acquired } \\
\hline Targets in US & $84.47 \%$ & $100 \%$ & $1.1 \%$ & $100 \%$ & $67.3 \%$ \\
\hline $\begin{array}{l}\text { Other developed market } \\
\text { targets }\end{array}$ & $74.95 \%$ & $100 \%$ & $1 \%$ & $100 \%$ & $67.2 \%$ \\
\hline Emerging-market targets & $50.94 \%$ & $49 \%$ & $0.37 \%$ & $100 \%$ & $57.3 \%$ \\
\hline
\end{tabular}

Notes: This table summarizes the deal value and target stake acquired for the 62 US firms in the sample which announced M\&A transactions in emerging markets and other M\&A transactions in developed markets from 1990 to 2002 by the geographic region where the target is present. All data is collected from SDC. Data was consistently available for all characteristics except method of payment which suffers from missing data in Panel A. Data was also not consistently available for transaction value or target stake acquired and thus the percent of the sample with data is reported in the final column of Panel B. 
Table 4. Joint Returns Increase When a Cross-Border M\&A Transaction Is Announced.

\begin{tabular}{|c|c|c|}
\hline \multicolumn{3}{|c|}{ Full Sample } \\
\hline $\begin{array}{l}\text { Joint Returns } \\
\text { (US\$) }\end{array}$ & Raw Returns & Market-Adjusted Returns \\
\hline$-1:+1$ & $2.28 \% * *$ & $1.79 \% * *$ \\
\hline$-2:+2$ & $1.73 \% * *$ & $1.08 \% *$ \\
\hline $\mathrm{N}$ & 224 & 221 \\
\hline \multicolumn{3}{|c|}{ Target in East Asia } \\
\hline $\begin{array}{c}\text { Joint Returns } \\
\text { (US\$ Returns) }\end{array}$ & $\begin{array}{l}\text { Raw } \\
\text { Returns }\end{array}$ & $\begin{array}{c}\text { Market-Adjusted } \\
\text { Returns } \\
\end{array}$ \\
\hline$-1:+1$ & $2.34 \% *$ & $2.29 \% * *$ \\
\hline $\mathrm{N}$ & 144 & 144 \\
\hline \multicolumn{3}{|c|}{ Target in Latin America } \\
\hline $\begin{array}{l}\text { Joint Returns } \\
\text { (US\$ Returns) }\end{array}$ & $\begin{array}{l}\text { Raw } \\
\text { Returns }\end{array}$ & $\begin{array}{l}\text { Market-Adjusted } \\
\text { Returns }\end{array}$ \\
\hline$-1:+1$ & $2.15 \% *$ & $0.86 \%$ \\
\hline $\mathrm{N}$ & 80 & 77 \\
\hline \multicolumn{3}{|c|}{ Acquirer Gains Majority Control of Emerging-Market Target } \\
\hline $\begin{array}{l}\text { Joint Returns } \\
\text { (US\$ Returns) }\end{array}$ & $\begin{array}{l}\text { Raw } \\
\text { Returns }\end{array}$ & $\begin{array}{l}\text { Market-Adjusted } \\
\text { Returns }\end{array}$ \\
\hline$-1:+1$ & $7.42 \% * * *$ & $5.89 \% * * *$ \\
\hline $\mathrm{N}$ & 55 & 55 \\
\hline
\end{tabular}

Notes: This table summarizes average stock market reactions to the announcement of cross-border M\&A transactions involving a public acquirer from a developed market and a public target from a developing market. Averages are reported in standardized monthly return units. The sample size is based on a subset of transactions where stock price data was available for acquirertarget pairs $(\mathrm{N}=224) .-1:+1$ is a symmetric 3 -week event window and $-2:+2$ is a symmetric 5 -week event window around the week of the announcement. Returns are calculated using continuous compounding of the percent changes in the weekly closing stock prices (equivalent to a buy-and-hold methodology). Raw returns are unadjusted average returns. Market-adjusted returns are calculated by subtracting the market return from the raw return for any given firm. Joint returns are calculated as market-capitalization-weighted average returns for both the target and the acquirer using dollar-denominated returns for both parties. $* * *$, and $* * *$ denote statistical significance at the $10 \%, 5 \%$ and $1 \%$ levels, respectively. 
Table 5. The Acquisition of Majority Control of the Target Drives Joint Returns in Cross-Border M\&A Transactions.

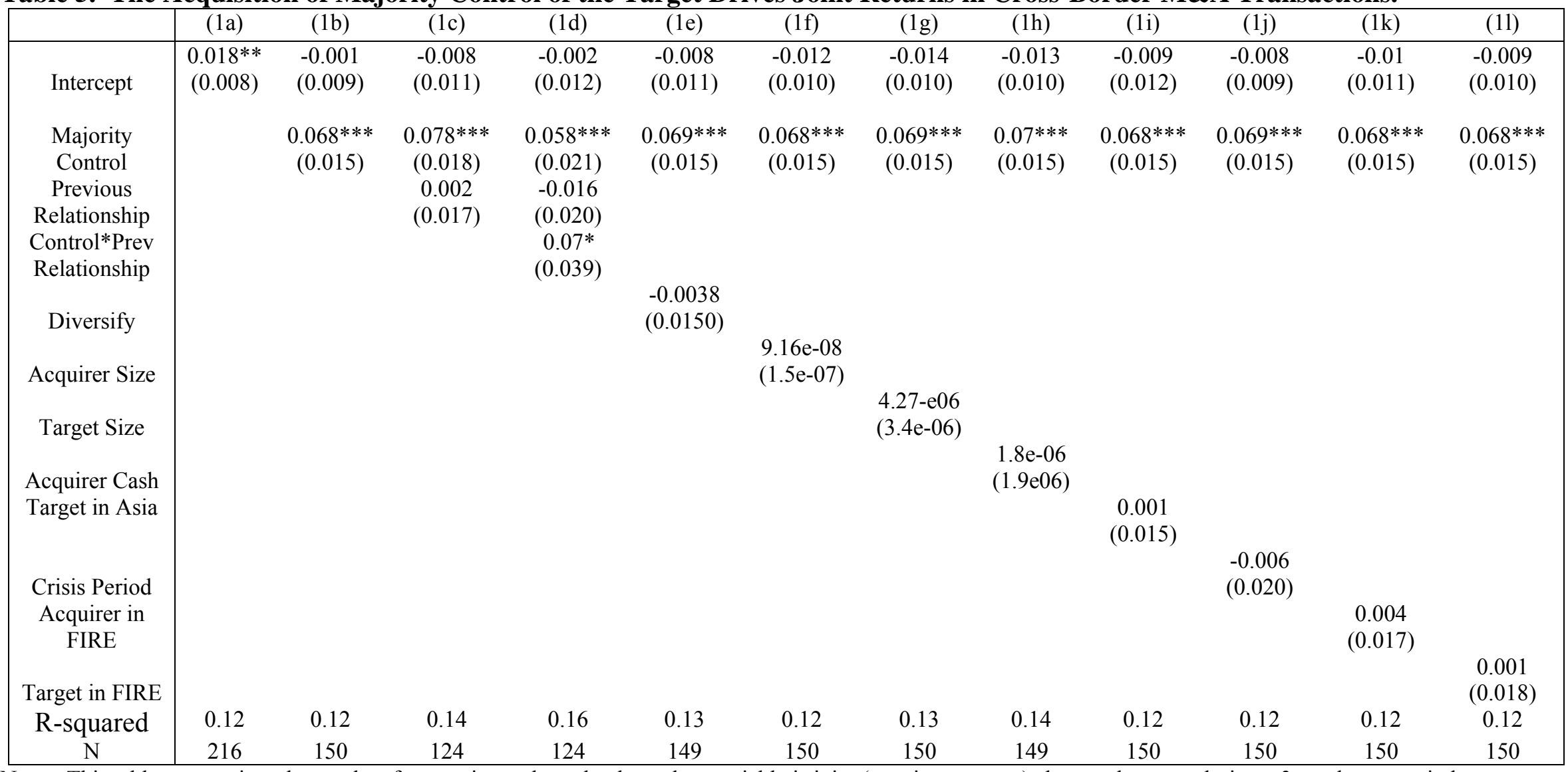

Notes: This table summarizes the results of regressions where the dependent variable is joint (acquirer + target) abnormal returns during a 3-week event window (standardized to monthly return units) around the announcement date. Mean coefficient estimates are reported with standard errors in parentheses. All M\&A transactions in the sample involve a public acquirer from a developed market and a public target from an emerging market. Joint returns are market-capitalizationweighted averages of acquirer and target returns and US\$-denominated. Weekly abnormal returns are calculated using a market model and are continuously compounded, then standardized to monthly units. The acquisition of control is a dummy variable identified if the acquirer holds $50 \%$ or more of the target firm's equity following the acquisition and did not previously have control. Previous relationship is a dummy variable that takes on a value of one if the acquirer held equity in the target firm prior to the acquisition. Diversification is a dummy variable that takes on a value of one if the absolute value of the difference in SIC codes between acquirer and target is 1000 or greater. Acquirer and target size and acquirer cash is measured in US\$ million. Emerging markets included are Indonesia, Malaysia, Philippines, South Korea, Thailand, Argentina, Brazil, Chile, and Mexico. The developed markets include Canada, France, Germany, Hong Kong, Italy, Japan, Netherlands, Singapore, Spain, the United Kingdom, and the United States. Crisis period is a dummy variable that takes on a value of one if the target country is in a currency crisis. Acquirer and target FIRE dummies take on a value of one if the firm has an SIC code between 6000 and 6999 . *, **, and *** denote statistical significance at the $10 \%, 5 \%$ and $1 \%$ levels, respectively. 
Table 6A. Cross-border M\&A Transactions Create Value for both Acquirers and Targets.

\begin{tabular}{|c|c|c|c|c|}
\hline Panel A & $\begin{array}{l}\text { Develop } \\
\text { (Local }\end{array}$ & $\begin{array}{l}\text { ket Acquirer } \\
\text { cy Returns) }\end{array}$ & \multicolumn{2}{|c|}{$\begin{array}{l}\text { Emerging-Market Target } \\
\text { (Local Currency Returns) }\end{array}$} \\
\hline Full Sample & $\begin{array}{l}\text { Raw } \\
\text { Returns }\end{array}$ & $\begin{array}{l}\text { Market-Adjusted } \\
\text { Returns }\end{array}$ & $\begin{array}{l}\text { Raw } \\
\text { Returns }\end{array}$ & $\begin{array}{l}\text { Market-Adjusted } \\
\text { Returns }\end{array}$ \\
\hline $\begin{array}{l}-1:+1 \\
-2:+2\end{array}$ & $\begin{array}{l}3.05 \% * * * \\
2.00 \% * *\end{array}$ & $\begin{array}{c}2.43 \% * * \\
1.26 \%\end{array}$ & $\begin{array}{l}6.68 \% * * * \\
5.51 \% * * *\end{array}$ & $\begin{array}{l}6.87 \% * * * \\
5.05 \% * * *\end{array}$ \\
\hline $\mathrm{N}$ & 346 & 346 & 299 & 299 \\
\hline
\end{tabular}

\begin{tabular}{|c|c|c|c|c|}
\hline Panel B & $\begin{array}{r}\text { Develop } \\
\text { (Local }\end{array}$ & $\begin{array}{l}\text { larket Acquirer } \\
\text { ency Returns) }\end{array}$ & \multicolumn{2}{|c|}{$\begin{array}{l}\text { Emerging-Market Target } \\
\text { (Local Currency Returns) }\end{array}$} \\
\hline East Asia & $\begin{array}{l}\text { Raw } \\
\text { Returns }\end{array}$ & $\begin{array}{l}\text { Market-Adjusted } \\
\text { Returns }\end{array}$ & $\begin{array}{l}\text { Raw } \\
\text { Returns }\end{array}$ & $\begin{array}{l}\text { Market-Adjusted } \\
\text { Returns }\end{array}$ \\
\hline$-1:+1$ & $3.45 \% * *$ & $2.70 * *$ & $5.17 \% *$ & $5.17 \% *$ \\
\hline $\mathrm{N}$ & 230 & 230 & 188 & 188 \\
\hline Panel C & \multicolumn{2}{|c|}{$\begin{array}{l}\text { Developed Market Acquirer } \\
\text { (Local Currency Returns) }\end{array}$} & \multicolumn{2}{|c|}{$\begin{array}{l}\text { Emerging-Market Target } \\
\text { (Local Currency Returns) }\end{array}$} \\
\hline Latin America & $\begin{array}{l}\text { Raw } \\
\text { Returns }\end{array}$ & $\begin{array}{l}\text { Market-Adjusted } \\
\text { Returns }\end{array}$ & $\begin{array}{l}\text { Raw } \\
\text { Returns }\end{array}$ & $\begin{array}{l}\text { Market-Adjusted } \\
\text { Returns }\end{array}$ \\
\hline$-1:+1$ & $2.23 \% * *$ & $1.89 \% * *$ & $9.18 \% * * *$ & $9.68 \% * * *$ \\
\hline $\mathrm{N}$ & 116 & 116 & 111 & 111 \\
\hline Panel D & \multicolumn{2}{|c|}{$\begin{array}{l}\text { Developed Market Acquirer } \\
\text { (Local Currency Returns) }\end{array}$} & \multicolumn{2}{|c|}{$\begin{array}{l}\text { Emerging-Market Target } \\
\text { (Local Currency Returns) }\end{array}$} \\
\hline Majority Control Acquired & $\begin{array}{l}\text { Raw } \\
\text { Returns }\end{array}$ & $\begin{array}{l}\text { Market-Adjusted } \\
\text { Returns }\end{array}$ & $\begin{array}{l}\text { Raw } \\
\text { Returns }\end{array}$ & $\begin{array}{l}\text { Market-Adjusted } \\
\text { Returns }\end{array}$ \\
\hline$-1:+1$ & $5.66 \% * * *$ & $3.99 \% * * *$ & $9.87 \% * * *$ & $8.92 \% * * *$ \\
\hline $\mathrm{N}$ & 92 & 92 & 85 & 85 \\
\hline
\end{tabular}

Notes: This table summarizes average stock market reactions to the announcement of a cross-border acquisition involving a public acquirer from a developed market and a public target from a developing market for the full sample (Panel A) and by region (Panels B and C). Panel D summarizes average stock market reactions to the announcement of a cross-border acquisition in which majority control is transferred to the acquirer. Averages are reported in standardized monthly return units. East Asian emerging markets include Indonesia, Malaysia, Philippines, South Korea, and Thailand. Latin American emerging markets include Argentina, Brazil, Chile, and Mexico. The developed markets include Canada, France, Germany, Hong Kong, Italy, Japan, Netherlands, Singapore, Spain, the United Kingdom, and the United States. The event window comprises a symmetric 3- or 5-week period. Returns are calculated using continuous compounding of the percent changes in the weekly equity closing prices (equivalent to a buy and hold methodology). Raw returns are unadjusted average returns. Market-adjusted returns are alculated by subtracting the market return from the raw return for any given firm. $*, * *$, and $* * *$ denote statistical significance at the $10 \%, 5 \%$ and $1 \%$ levels, respectively. 
Table 6B. Majority Control is Accompanied by Higher Value Gains for Acquirers and Targets.

\begin{tabular}{|c|c|c|}
\hline \multicolumn{3}{|c|}{ Panel A: Full Sample } \\
\hline & $\begin{array}{c}\text { Developed-Market Acquirer } \\
\text { (US\$ Returns) }\end{array}$ & $\begin{array}{l}\text { Emerging-Market Target } \\
\text { (US\$ Returns) }\end{array}$ \\
\hline Average & $\begin{array}{l}2.34 \% * * \\
(0.013)\end{array}$ & $\begin{array}{l}7.07 \% * * * \\
(0.002)\end{array}$ \\
\hline Median & $\begin{array}{l}0.91 \% \\
(0.027)\end{array}$ & $\begin{array}{l}1.55 \% \\
(0.026)\end{array}$ \\
\hline \multicolumn{3}{|c|}{ Panel B: Acquirer Gains Control of Emerging-Market Target } \\
\hline & $\begin{array}{l}\text { Developed-Market Acquirer } \\
\text { (US\$ Returns) }\end{array}$ & $\begin{array}{l}\text { Emerging-Market Target } \\
\text { (US\$ Returns) }\end{array}$ \\
\hline Average & $\begin{array}{l}4.06 \% * * * \\
(0.001)\end{array}$ & $\begin{array}{c}10.02 \% * * \\
(0.05)\end{array}$ \\
\hline Median & $\begin{array}{l}3.97 \% \\
(0.001)\end{array}$ & $\begin{array}{l}0.84 \% \\
(0.111)\end{array}$ \\
\hline \multicolumn{3}{|c|}{ Panel C: Acquirer Does Not Gain Control of Emerging-Market Target } \\
\hline & $\begin{array}{c}\text { Developed-Market Acquirer } \\
\text { (US\$ Returns) }\end{array}$ & $\begin{array}{l}\text { Emerging-Market Target } \\
\text { (US\$ Returns) }\end{array}$ \\
\hline Average & $\begin{array}{l}0.47 \% \\
(0.51)\end{array}$ & $\begin{array}{c}4.88 \% * \\
(0.10)\end{array}$ \\
\hline Median & $\begin{array}{l}0.42 \% \\
(0.42) \\
\end{array}$ & $\begin{array}{l}1.41 \% \\
(0.41) \\
\end{array}$ \\
\hline \multicolumn{3}{|c|}{ Panel D: Market Capitalization Values } \\
\hline & $\begin{array}{c}\text { Developed-Market Acquirer } \\
\text { (Market Capitalization) }\end{array}$ & $\begin{array}{c}\text { Emerging-Market Target } \\
\text { (Market Capitalization) }\end{array}$ \\
\hline Average & \$33.48 Billion & \$895.81 Million \\
\hline Median & \$12.91 Billion & \$201.60 Million \\
\hline
\end{tabular}

Notes: This table summarizes average and median stock market reactions to the announcement of a cross-border acquisition involving a public acquirer from a developed market and a public target from a developing market for the full sample (Panel A), when the acquirer gains majority control (Panel B), and when the acquirer does not gain majority control (Panel C). Panel D summarizes the average and median stock market capitalization for acquirer and target firms. East Asian emerging markets include Indonesia, Malaysia, Philippines, South Korea, and Thailand. Latin American emerging markets include Argentina, Brazil, Chile, and Mexico. The developed markets include Canada, France, Germany, Hong Kong, Italy, Japan, Netherlands, Singapore, Spain, the United Kingdom, and the United States. The event window comprises a symmetric 3- week period which includes the week before and the week following the announcement. Returns are calculated using continuous compounding of the percent changes in the weekly equity closing prices (equivalent to a buy and hold methodology). Market-adjusted returns are calculated by subtracting the market return from the raw return for any given firm. P-values are reported in parentheses. *, **, and *** denote statistical significance at the $10 \%, 5 \%$ and $1 \%$ levels, respectively. 
Table 7. The Acquisition of Majority Control of the Target Drives Acquirer Returns in Cross-border M\&A Transactions.

\begin{tabular}{|c|c|c|c|c|c|c|c|c|c|c|c|c|}
\hline & (2a) & (2b) & $(2 \mathrm{c})$ & $(2 d)$ & $(2 \mathrm{e})$ & (2f) & $(2 \mathrm{~g})$ & (2h) & (2i) & $(2 \mathrm{j})$ & $(2 \mathrm{k})$ & (21) \\
\hline Intercept & $\begin{array}{c}0.024 \\
(0.009)^{* *}\end{array}$ & $\begin{array}{c}0.007 \\
(0.008)\end{array}$ & $\begin{array}{c}0.008 \\
(0.010)\end{array}$ & $\begin{array}{c}0.014 \\
(0.010)\end{array}$ & $\begin{array}{c}0.006 \\
(0.010)\end{array}$ & $\begin{array}{c}0.009 \\
(0.011)\end{array}$ & $\begin{array}{c}0.003 \\
(0.009)\end{array}$ & $\begin{array}{c}4.68 \mathrm{e}-04 \\
(0.010)\end{array}$ & $\begin{array}{c}0.004 \\
(0.009)\end{array}$ & $\begin{array}{c}0.009 \\
(0.008)\end{array}$ & $\begin{array}{c}0.010 \\
(0.010)\end{array}$ & $\begin{array}{c}0.011 \\
(0.009)\end{array}$ \\
\hline $\begin{array}{c}\text { Majority } \\
\text { Control }\end{array}$ & & $\begin{array}{l}0.033 * * \\
(0.013)\end{array}$ & $\begin{array}{l}0.043 * * * \\
(0.015)\end{array}$ & $\begin{array}{c}0.026 \\
(0.017)\end{array}$ & $\begin{array}{c}0.035 * * * \\
(0.013)\end{array}$ & $\begin{array}{c}0.033^{* *} \\
(0.013)\end{array}$ & $\begin{array}{l}0.046^{* * *} \\
(0.014)\end{array}$ & $\begin{array}{l}0.042 * * * \\
(0.015)\end{array}$ & $\begin{array}{l}0.048^{* * *} \\
(0.014)\end{array}$ & $\begin{array}{l}0.035^{* * *} \\
(0.013)\end{array}$ & $\begin{array}{c}0.031^{* *} \\
(0.013)\end{array}$ & $\begin{array}{c}0.033^{* *} \\
(0.013)\end{array}$ \\
\hline Previous & & & -0.004 & 0.021 & & & & & & & & \\
\hline Relationship & & & $(0.015)$ & $(0.017)$ & & & & & & & & \\
\hline $\begin{array}{l}\text { Control*Prev } \\
\text { Relationship }\end{array}$ & & & & $\begin{array}{l}0.060^{*} \\
(0.033)\end{array}$ & & & & & & & & \\
\hline Diversify & & & & & $\begin{array}{l}-0.001 \\
(0.013)\end{array}$ & & & & & & & \\
\hline Target in Asia & & & & & & $\begin{array}{l}-0.004 \\
(0.013)\end{array}$ & & & & & & \\
\hline Acquirer Size & & & & & & & $\begin{array}{c}2.96 \mathrm{e}-08 \\
(1.27 \mathrm{e}-07)\end{array}$ & & & & & \\
\hline Target Size & & & & & & & & $\begin{array}{c}5.30 \mathrm{e}-06 \\
(4.07 \mathrm{e}-06)\end{array}$ & & & & \\
\hline Acquirer Cash & & & & & & & & & $\begin{array}{c}-9.39 \mathrm{e}-08 \\
(1.70 \mathrm{e}-06)\end{array}$ & & & \\
\hline Crisis Period & & & & & & & & & & $\begin{array}{l}-0.017 \\
(0.018)\end{array}$ & & \\
\hline $\begin{array}{l}\text { Acquirer in } \\
\text { FIRE }\end{array}$ & & & & & & & & & & & $\begin{array}{l}-0.010 \\
(0.014)\end{array}$ & \\
\hline Target in FIRE & & & & & & & & & & & & $\begin{array}{l}-0.015 \\
(0.015)\end{array}$ \\
\hline R-squared & & 0.03 & 0.04 & 0.03 & 0.03 & 0.05 & 0.05 & 0.06 & 0.03 & 0.03 & 0.03 & 0.06 \\
\hline $\mathrm{N}$ & 341 & 237 & 198 & 234 & 237 & 210 & 198 & 209 & 237 & 237 & 235 & 198 \\
\hline
\end{tabular}

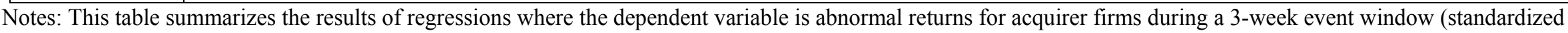
to monthly return units) around the announcement date on characteristics of the involved firms. Mean coefficient estimates are reported with standard errors in parentheses. All M\&A transactions in the sample involve a public acquirer from a developed market and a public target from an emerging market. Weekly abnormal returns are calculated using a market model and are continuously compounded, then standardized to monthly units. The acquisition of control is a dummy variable identified if the acquirer holds $50 \%$ or more of the target firm's equity following the acquisition and did not previously have control. Previous relationship is a dummy

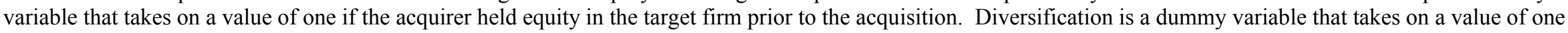

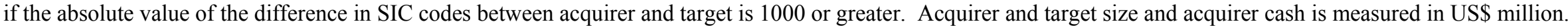
Emerging markets included are Indonesia, Malaysia, Philippines, South Korea, Thailand, Argentina, Brazil, Chile, and Mexico. Crisis period is a dummy variable that takes on a value of one if the target country is in a currency crisis. Acquirer and target FIRE dummies take on a value of one if the firm has an SIC code between 6000 and 6999 . * **, and *** denote statistical significance at the $10 \%, 5 \%$ and $1 \%$ levels, respectively. 
Table 8. The Acquisition of Majority Control of the Target Does Not Drive Target Returns in Cross-border M\&A Transactions.

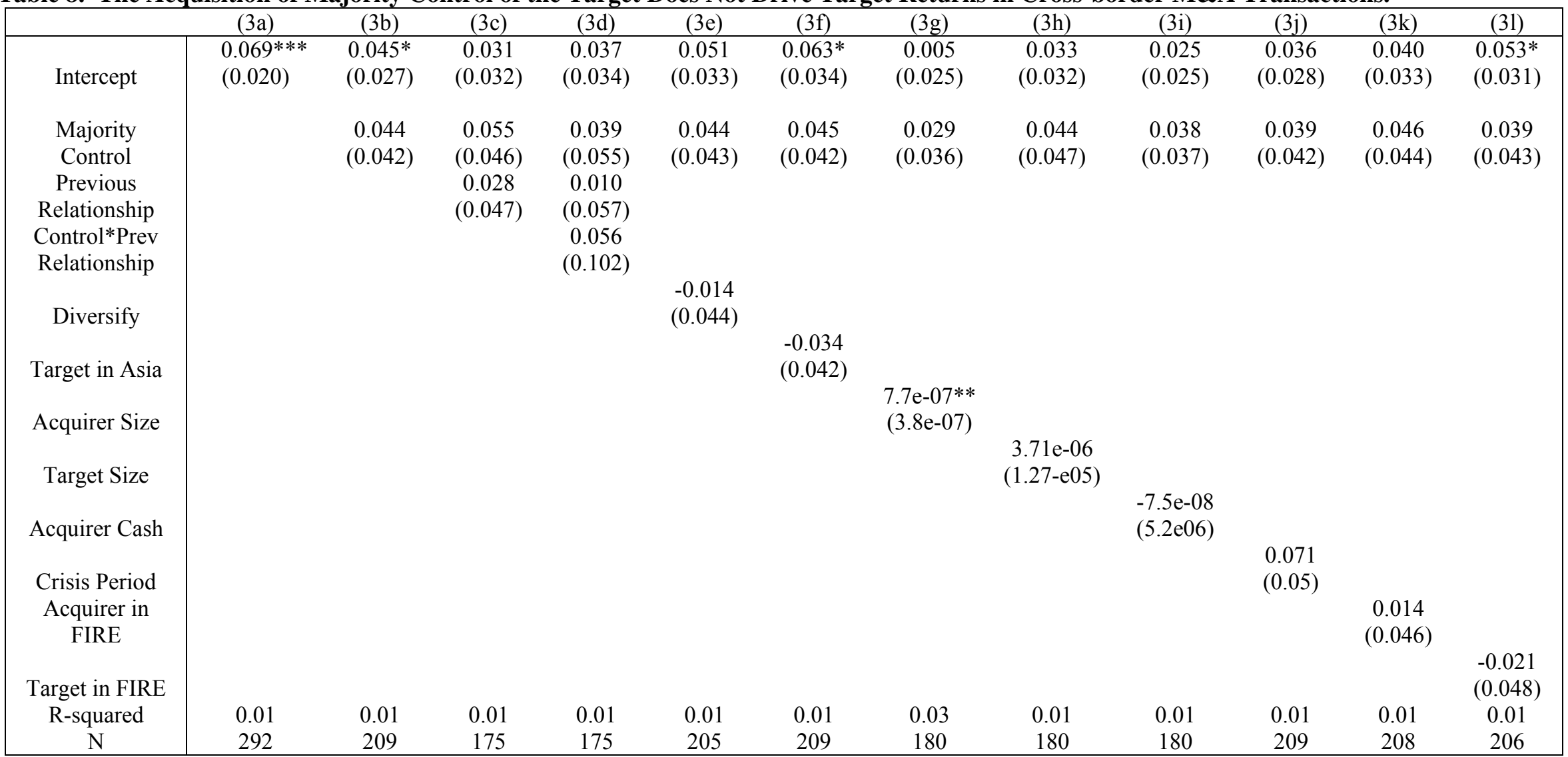

Notes: This table summarizes the results of regressions where the dependent variable is market adjusted target returns during a 3-week event window (standardized to monthly return units) around the announcement date. Mean coefficient estimates are reported with standard errors in parentheses. All M\&A transactions in the sample involve a public acquirer from a developed market and a public target from an emerging market. Weekly abnormal returns are calculated using a market model and are continuously compounded, then standardized to monthly units. The acquisition of control is a dummy variable identified if the acquirer holds $50 \%$ or more of the target firm's equity following the acquisition and did not previously have control. Previous relationship is a dummy variable that takes on a value of one if the acquirer held equity in the target firm prior to the acquisition. Diversification is a dummy variable that takes on a value of one if the absolute value of the difference in SIC codes between acquirer and target is 1000 or greater. Acquirer and target size and acquirer cash is measured in US\$ million. Emerging markets included are Indonesia, Malaysia, Philippines, South Korea, Thailand, Argentina, Brazil, Chile, and Mexico. Crisis period is a dummy variable that takes on a value of one if the target country is in a currency crisis. Acquirer and target FIRE dummies take on a value of one if the firm has an SIC code between 6000 and 6999 . *, **, and $* * *$ denote statistical significance at the $10 \%, 5 \%$ and $1 \%$ levels, respectively. 
Table 9. Do Crisis Periods Affect the Creation of Value?

\begin{tabular}{|c|c|c|c|c|c|c|c|c|c|c|}
\hline & \multicolumn{6}{|c|}{ Panel A } & \multicolumn{4}{|c|}{ Panel B } \\
\hline & (1a) & (2a) & (3a) & (4a) & (5a) & (6a) & (1b) & $(2 b)$ & (3b) & $(4 b)$ \\
\hline Intercept & $\begin{array}{l}0.033 * * * \\
(0.011)\end{array}$ & $\begin{array}{l}0.026^{* *} \\
(0.013) \\
\end{array}$ & $\begin{array}{l}0.013 \\
(0.011)\end{array}$ & $\begin{array}{l}0.011 \\
(0.009)\end{array}$ & $\begin{array}{l}0.009 \\
(0.009)\end{array}$ & $\begin{array}{l}0.002 \\
(0.009)\end{array}$ & $\begin{array}{l}0.035^{* * *} \\
(0.012)\end{array}$ & $\begin{array}{c}0.035 * * * \\
(0.013)\end{array}$ & $\begin{array}{l}0.009 \\
(0.01)\end{array}$ & $\begin{array}{l}0.011 \\
(0.011)\end{array}$ \\
\hline $1988-1996$ & $\begin{array}{l}-0.039^{*} \\
(0.023)\end{array}$ & & & $\begin{array}{l}-0.014 \\
(0.015)\end{array}$ & & & & & & \\
\hline $1997-1999$ & & $\begin{array}{c}-0.004 \\
(0.019) \\
\end{array}$ & & & $\begin{array}{l}-0.004 \\
(0.013)\end{array}$ & & & & & \\
\hline $2000-2003$ & & & $\begin{array}{l}0.034^{*} \\
(0.020)\end{array}$ & & & $\begin{array}{l}0.017 \\
(0.014)\end{array}$ & & & & \\
\hline EMBI spread & & & & & & & $\begin{array}{l}0.117 * * \\
(0.053)\end{array}$ & $\begin{array}{c}0.131 * * \\
(0.058) \\
\end{array}$ & $\begin{array}{l}0.005 \\
(0.043) \\
\end{array}$ & $\begin{array}{l}-0.008 \\
(0.035) \\
\end{array}$ \\
\hline Crisis period & & & & & & & & $\begin{array}{l}-0.051 \\
(0.055)\end{array}$ & & $\begin{array}{l}-0.016 \\
(0.025)\end{array}$ \\
\hline Majority Control & & & & $\begin{array}{l}0.031 * * \\
(0.013)\end{array}$ & $\begin{array}{l}0.034 * * \\
(0.013)\end{array}$ & $\begin{array}{l}0.033 * * \\
(0.013)\end{array}$ & & & $\begin{array}{l}0.031 * * \\
(0.015)\end{array}$ & $\begin{array}{l}0.034 * * \\
(0.016)\end{array}$ \\
\hline EMBI* Crisis & & & & & & & & $\begin{array}{l}-0.278 \\
(0.245) \\
\end{array}$ & & \\
\hline EMBI*Control & & & & & & & & & $\begin{array}{l}-0.008 \\
(0.0687)\end{array}$ & \\
\hline EMBI* Crisis* Control & & & & & & & & & & $\begin{array}{c}0.027 \\
(0.163)\end{array}$ \\
\hline $\mathrm{N}$ & 341 & 341 & 341 & 237 & 237 & 237 & 263 & 263 & 180 & 180 \\
\hline R-squared & 0.0088 & 0.0001 & 0.0086 & 0.0309 & 0.0278 & 0.0334 & 0.0185 & 0.0234 & 0.02421 & 0.0286 \\
\hline
\end{tabular}

Notes: This table summarizes the results of regressions where the dependent variable is abnormal returns for acquirer firms during a 3-week event window (standardized to monthly return units) around the announcement date. Mean coefficient estimates are reported with standard errors in parentheses. The acquisition of control is a dummy variable identified if the acquirer holds $50 \%$ or more of the target firm's equity following the acquisition and did not previously have control. Crisis period is a dummy variable that takes on a value of one if the target country is in a currency crisis. EMBI is the relative value of the JP Morgan Emerging Market's Bond Index (EMBI) spread. *,**, and *** denote statistical significance at the $10 \%, 5 \%$ and $1 \%$ levels, respectively. 
Table 10. Value is Created By Acquiring Targets in Emerging Markets and Not Developed Markets.

\begin{tabular}{|c|c|c|c|c|c|c|c|c|c|c|}
\hline & $1 \mathrm{a}$ & $1 \mathrm{~b}$ & $1 \mathrm{c}$ & $1 \mathrm{~d}$ & $1 \mathrm{e}$ & 1f & $1 \mathrm{~g}$ & $1 \mathrm{~h}$ & $1 \mathrm{i}$ & $1 \mathrm{j}$ \\
\hline Intercept & $\begin{array}{l}-0.0002 \\
(0.003)\end{array}$ & $\begin{array}{l}-0.0038 \\
(0.004)\end{array}$ & $\begin{array}{l}-0.0002 \\
(0.01)\end{array}$ & $\begin{array}{l}0.008 \\
(0.011)\end{array}$ & $\begin{array}{c}0.006 \\
(0.012)\end{array}$ & $\begin{array}{l}0.0013 \\
(0.013)\end{array}$ & $\begin{array}{l}0.013 \\
(0.011)\end{array}$ & $\begin{array}{l}0.012 \\
(0.011)\end{array}$ & $\begin{array}{l}-0.009 \\
(0.013)\end{array}$ & $\begin{array}{l}-0.009 \\
(0.013)\end{array}$ \\
\hline $\begin{array}{l}\text { Emerging-market } \\
\text { Target }\end{array}$ & & $\begin{array}{l}0.033 * * \\
(0.013)\end{array}$ & $\begin{array}{l}0.033 * * \\
(0.017)\end{array}$ & $\begin{array}{l}-0.007 \\
(0.024)\end{array}$ & $\begin{array}{l}-0.007 \\
(0.024)\end{array}$ & $\begin{array}{l}0.0144 \\
(0.028)\end{array}$ & $\begin{array}{l}-0.008 \\
(0.023)\end{array}$ & $\begin{array}{l}0.00002 \\
(0.025)\end{array}$ & $\begin{array}{l}-0.0004 \\
(0.03)\end{array}$ & $\begin{array}{l}-0.003 \\
(0.031)\end{array}$ \\
\hline Majority Control & & & $\begin{array}{l}-0.0023 \\
(0.011)\end{array}$ & $\begin{array}{l}-0.012 \\
(0.012)\end{array}$ & $\begin{array}{c}-.009 \\
(0.013)\end{array}$ & $\begin{array}{l}-0.006 \\
(0.014)\end{array}$ & $\begin{array}{l}-0.013 \\
(0.012)\end{array}$ & $\begin{array}{l}-0.013 \\
(0.012)\end{array}$ & $\begin{array}{l}0.002 \\
(0.016)\end{array}$ & $\begin{array}{l}0.002 \\
(0.016)\end{array}$ \\
\hline $\begin{array}{l}\text { Emerging-market } \\
\text { Target* Control }\end{array}$ & & & & $\begin{array}{l}0.075 * * \\
(0.032)\end{array}$ & $\begin{array}{c}0.0738 * * \\
(0.032) \\
\end{array}$ & $\begin{array}{l}0.058 * \\
(0.033) \\
\end{array}$ & $\begin{array}{l}0.075 * * \\
(0.032)\end{array}$ & $\begin{array}{l}0.077 * * \\
(0.032)\end{array}$ & $\begin{array}{l}0.129 * * * \\
(0.04)\end{array}$ & $\begin{array}{l}0.122 * * * \\
(0.044)\end{array}$ \\
\hline $\begin{array}{l}\text { Previous } \\
\text { Relationship }\end{array}$ & & & & & $\begin{array}{c}0.005 \\
(0.017)\end{array}$ & $\begin{array}{c}0.018 \\
(0.019)\end{array}$ & & & & \\
\hline $\begin{array}{l}\text { Previous } \\
\text { Relationship* } \\
\text { Emerging-market } \\
\text { Target }\end{array}$ & & & & & & $\begin{array}{l}-0.056 \\
(0.039)\end{array}$ & & & & \\
\hline Diversify & & & & & & & $\begin{array}{l}-0.013 \\
(0.01) \\
\end{array}$ & $\begin{array}{l}-.001 \\
(0.011)\end{array}$ & & \\
\hline $\begin{array}{l}\text { Diversify* } \\
\text { Emerging-market } \\
\text { Target }\end{array}$ & & & & & & & & $\begin{array}{l}-0.036 \\
(0.036) \\
\end{array}$ & & \\
\hline $\begin{array}{l}\text { Value of } \\
\text { Transaction }\end{array}$ & & & & & & & & & $\begin{array}{l}0.000001 \\
(0.000001)\end{array}$ & $\begin{array}{l}0.000001 \\
(0.000001) \\
\end{array}$ \\
\hline $\begin{array}{l}\text { Emerging-market } \\
\text { Target * Value } \\
\text { of Transaction }\end{array}$ & & & & & & & & & & $\begin{array}{l}0.000029 \\
(0.000035)\end{array}$ \\
\hline $\begin{array}{l}\text { Firm Fixed } \\
\text { Effects Included }\end{array}$ & $\mathrm{NO}$ & YES & YES & YES & YES & YES & YES & YES & YES & YES \\
\hline \multicolumn{11}{|l|}{ R-squared } \\
\hline $\mathrm{N}$ & 1235 & 1235 & 843 & 843 & 843 & 843 & 1235 & 1235 & 843 & 843 \\
\hline
\end{tabular}

Notes: This table summarizes the results of regressions where the dependent variable is abnormal returns for acquirer firms during a 3-week event window (standardized to monthly return units) around the announcement date. Mean coefficient estimates are reported with standard errors in parentheses. All M\&A transactions in the sample involve a public acquirer from a developed market and a public target from an emerging market, or a target in Canada, Europe, Hong Kong, Japan, Singapore or the United States. The acquisition of control is a dummy variable identified if the acquirer holds $50 \%$ or more of the target firm's equity following the acquisition and did not previously have control. Previous relationship is a dummy variable that takes on a value of one if the acquirer held equity in the target firm prior to the acquisition. Diversification is a dummy variable that takes on a value of one if the absolute value of the difference in SIC codes between acquirer and target is 1000 or greater. Crisis period is a dummy variable that takes on a value of one if the target country is in a currency crisis. *, **, and *** denote statistical significance at the $10 \%, 5 \%$ and $1 \%$ levels, respectively. 
Table 11. Majority Control Matters More in R\&D Intensive Industries in Emerging Markets.

\begin{tabular}{|c|c|c|c|c|c|c|}
\hline & 1 & 2 & 3 & 4 & 5 & 6 \\
\hline Intercept & $\begin{array}{c}0.007 \\
(0.008) \\
\end{array}$ & $\begin{array}{c}0.007 \\
(0.008) \\
\end{array}$ & $\begin{array}{c}0.012 \\
(0.008) \\
\end{array}$ & $\begin{array}{l}0.062 * \\
(0.033)\end{array}$ & $\begin{array}{l}0.063 * \\
(0.033)\end{array}$ & $\begin{array}{l}0.061 * \\
(0.034)\end{array}$ \\
\hline Majority Control & $\begin{array}{l}0.033 * * \\
(0.013)\end{array}$ & $\begin{array}{l}0.033 * * \\
(0.013)\end{array}$ & $\begin{array}{l}0.024^{*} \\
(0.014)\end{array}$ & $\begin{array}{l}-0.012 \\
(0.012)\end{array}$ & $\begin{array}{l}-0.012 \\
(0.012)\end{array}$ & $\begin{array}{c}-0.011 \\
(0.014)\end{array}$ \\
\hline Rdintensity & & $\begin{array}{c}0.000 \\
(0.003)\end{array}$ & $\begin{array}{c}-0.013 * * \\
(0.006)\end{array}$ & & $\begin{array}{l}-0.001 \\
(0.002)\end{array}$ & $\begin{array}{c}-0.001 \\
(0.004)\end{array}$ \\
\hline Rdintensity* Control & & & $\begin{array}{l}0.019 * * * \\
(0.007)\end{array}$ & & & $\begin{array}{l}-0.001 \\
(0.005)\end{array}$ \\
\hline Emerging-market Target & & & & $\begin{array}{l}-0.007 \\
(0.024)\end{array}$ & $\begin{array}{l}-0.008 \\
(0.024) \\
\end{array}$ & $\begin{array}{c}0.011 \\
(0.026) \\
\end{array}$ \\
\hline $\begin{array}{l}\text { Emerging-market } \\
\text { Target*Control }\end{array}$ & & & & $\begin{array}{l}0.074 * * \\
(0.032)\end{array}$ & $\begin{array}{l}0.075 * * \\
(0.032)\end{array}$ & $\begin{array}{c}0.043 \\
(0.035) \\
\end{array}$ \\
\hline $\begin{array}{l}\text { Rdintensity*Emerging-market } \\
\text { Target }\end{array}$ & & & & & & $\begin{array}{c}-0.035 * * * \\
(0.013)\end{array}$ \\
\hline $\begin{array}{l}\text { Emerging-market } \\
\text { Target*Control*Rdintensity }\end{array}$ & & & & & & $\begin{array}{l}0.044 * * * \\
(0.015) \\
\end{array}$ \\
\hline Firm Fixed Effects Included & No & No & No & Yes & Yes & Yes \\
\hline R-squared & 0.027 & 0.028 & 0.057 & 0.345 & 0.346 & 0.355 \\
\hline $\mathrm{N}$ & 237 & 236 & 236 & 838 & 838 & 838 \\
\hline
\end{tabular}

Notes: This table summarizes the results of regressions where the dependent variable is abnormal returns for acquirer firms during a 3-week event window (standardized to monthly return units) around the announcement date. Mean coefficient estimates are reported with standard errors in parentheses. M\&A transactions in the sample for regressions 1-3 involve a public acquirer from a developed market and a public target from an emerging market. Regressions 4-6 extend the sample of targets to include developed market targets. The acquisition of control is a dummy variable identified if the acquirer holds $50 \%$ or more of the target firm's equity following the acquisition and did not previously have control. Rdintensity is a measure that is constructed using all US firms in Compustat from 1990 to 2002. The research and development expense (Compustat data item \#46) is divided by net sales (Compustat data item \#12) for all firms. This measure is sorted by 2-digit SIC codes, and an average measure of R\&D intensity by 2-digit SIC code is constructed. The measure of R\&D intensity is then matched by industry with the 2-digit SIC code of the emerging-market targets. $*, * *$, and $* * *$ denote statistical significance at the $10 \%, 5 \%$ and $1 \%$ levels, respectively. 